\title{
HORSEMEN FROM THE RHINE. EARLY ROMAN MILITARY EQUIPMENT FROM CAPIDAVA (I)
}

ALEXANDRU RAȚIU

IOAN C. OPRIȘ

\section{REZUMAT:}

Articolul aduce în prim plan descoperirile de echipament militar roman din ultimile patru campanii de la Capidava, respectiv între anii 2015 și 2019. Echipamentul prezentat este, în marea parte a sa, caracteristic echipamentului călăreților auxiliari romani din secolele I-II p. Chr. Piesele au fost descoperite în contextul cel mai timpuriu cercetat vreodată la Capidava, respectiv prima fază de piatră a castrului, mai exact ruinele unor clădiri, pe care le bănuim a fi barăci militare, situate în retentura dextra. Aceste clădiri au fost descoperite cu ocazia cercetării arheologice exhaustive a edificiului numit Principia romană târzie, o clădire mare cu absidă, care datează din secolul IV p. Chr. Acesta suprapune barăcile timpurii, care au fost anterior demolate până la nivelul primei asize de elevație din zidărie de piatră legată cu pământ.

\section{ABSTRACT:}

This paper emphasizes on the discoveries of Roman military equipment from the last four campaigns from Capidava (2015 - 2019). The equipment presented is, for the most part, characteristic of the equipment of Roman auxiliary horsemen from the $1^{\text {st }}$ and $2^{\text {nd }}$ centuries $\mathrm{AD}$. The artefacts were discovered in the earliest context ever researched at Capidava, respectively the first stone-masonry phase of the fort, more precisely the remains of some buildings, which we believe to be military barracks, located in the retentura dextra. These buildings were discovered during the exhaustive archaeological research of the building that we believe to be the Late Roman Principia, a large building with an apse, dating from the $4^{\text {th }}$ century AD. It overlaps the early barracks, which were previously demolished to the level of the first elevation course, made from stone masonry bonded with earth mortar.

CUVINTE CHEIE: Echipament militar roman, pandantiv trifid, limes-ul Dunării de Jos, cavalerie romană, castrul auxiliar

KEYWORDS: Roman Military Equipment, Trifid pendant, Lower Danube limes, Roman Cavalry, Roman Auxiliary Fort

\section{Introduction}

The present paper covers the recent discoveries (2015-2019) from Capidava as part of the wider archaeological research project of the 'Late Roman Principia', a large building with an apse, dating from the $4^{\text {th }}$ century AD, located in the south corner of the Late Roman Capidava Fort (Pl. I/1). Capidava is a Roman and later EarlyByzantine fort situated on the Lower Danube limes, as part of the province of Moesia Inferior, later Scythia ${ }^{1}$.

The publication of this material aims to bring further proof of the early Roman occupation level from the Lower Danube area, especially at Capidava. We have only recently published the balneum from Capidava, dated between the $2^{\text {nd }}$ and $3^{\text {rd }}$ centuries and the main gate of the nearby fort (porta principalis dextra, if not porta praetoria) ${ }^{2}$. However, both excavations revealed a limited quantity of small finds and conclusive artefacts, in general, relevant for dating purposes. The present endeavor is meant to bring some clarity to this subject through the publication of the first materials dating from the early centuries and to raise once more the question about the origins of the Capidava fort.

\footnotetext{
For the historical overview, see the introduction to our latest monograph, Opriş and Rațiu 2017, 13-24.

2 See, lately, Opriș et al. 2018; Opriș and Rațiu 2019a (Early Roman balneum); Opriș and Rațiu 2019b, 127 (main southern gate).
} 
The Roman military equipment presented here is characteristic of the cavalry equipment from the $1^{\text {st }}$ century $\mathrm{AD}$. The artefacts were discovered in the earliest context ever researched at Capidava, respectively its first phase of construction. The archaeological context of the finds consists of the remains of some buildings, which we believe belong to the barrack blocks, located in the retentura dextra. These buildings were discovered during the exhaustive archaeological research of the building called the Late Roman Headquarters. The apse building overlapped the previous barracks, which were demolished to the level of the first stone course of the masonry.

\section{Archaeological context and dating}

The excavations at the 'Late Roman Principia' began in 1957 with the research of the early medieval context consisting of several sunken hovels that were overlapping the building ${ }^{3}$. The archaeological research of this edifice was resumed in $2013^{4}$ and was planned, according to a multiannual plan, involving an open-area excavation (squares of $4 \times 4 \mathrm{~m}$ ). The building was divided by topographic means, first into 20 and then 28 such squares. Their excavation was carried on a predetermined order to allow the recording of as much stratigraphic information as possible. During the archaeological research, six different archaeological contexts were excavated, dating from the $1^{\text {st }}$ to the $11^{\text {th }} \mathrm{c}$. AD.

The pieces of equipment were discovered in Context no. 6, the earliest context excavated until now from Capidava. An array of buildings, a paved street and a well represent this context; all preserved only in a thin layer of maximum $0.40 \mathrm{~m}$, underneath the $4^{\text {th }}$ c. Principia. In order to erect the larger Late Roman Principia, the ground needed to be leveled, and many of the former structures were destroyed on that occasion. However, some of the features of these structures were preserved at the ground level, mainly the floor and one or two courses of masonry. The floors of the barracks are made of hardened clay and have a thin layer of burning. On these floors, within what we think to have been the early Roman military barracks, the items here published were found.

The context is rich in artifacts, especially pottery shards, although the discoveries are not distributed evenly on the entire surface of the context. Inside the barracks fragments of terra sigillata and other fine wares were found $^{5}$, along with the military equipment presented here and items such as a folded knife, glass fragments and a few bronze coins (the majority from Vespasian, but some as early as Claudius $\mathrm{I}^{6}$ ). Outside the barracks near the fountain, a large quantity of amphorae fragments were discovered, most of them belonging to Shelov B type ${ }^{7}$. The amphorae were very fragmented, nevertheless after counting singular necks and rims we estimated that as many as 36 different amphorae were discarded in that place. We are taking into the account the possibility of a rubbish pit, even though the pit itself was not found during the $\mathrm{dig}^{8}$.

The masonry is made of earth-bounded stone and it is preserved only at a height of a single course from the elevation. The walls are $0.6 \mathrm{~m}$ thick, the foundations are shallow, with one or two courses of smaller stones compared to those used for the elevation courses. The floor, as mentioned above, is made of battered clay, and has a thickness of $10 \mathrm{~cm}$.

The area South from Barracks No.1 and Barracks No.2 represents a paved street, made from medium sized limestone slabs (Pl. II). Part of this street is overlapped and destroyed by a medieval storage pit (Pl III/1 and Pl IV/2-4). When we re-excavated this pit ${ }^{9}$ we used the opportunity to record the stratigraphic situation underneath the Context no. 6 . The paved street was built on a layer of compacted sand that stands on natural soil, the very

\footnotetext{
3 See Florescu et al. 1959, pl. I. This first plan ever published included the short side of the horreum with the L-shaped corner pillar of its portico, part of the NE long side of the Late Roman headquarters and half of the building's southern pentagonal apsis and some 28 Middle Byzantine sunken hovels excavated during 1957 season. See also the general plan of the fort in the first monograph, Florescu et al. 1958, pl. I-II. Other important observations on the same principia building prior to the systematic research undertaken starting from the 2013 season belong to Radu Florescu, see Florescu 1975, especially 368-371. 4 Opriș et al. 2014, 35-36. Five subsequent campaigns followed in 2014 and in 2016-2019: Opriş et al. 2015; Opriș et al. 2017; Rațiu et al. 2018; Rațiu et al. 2019; Rațiu et al. 2020.

5 The pottery is still in the documentation stage, an ample study is forthcoming.

6 Courtesy of Mihai Dima, the numismatic expert involved with this project at Capidava. The coins are still under research and will be an important part of the general publication strategy. Besides these new $1^{\text {st }}$ century coins, one should remind the ones known before our recent excavations: two stray finds, a Republican $2^{\text {nd }}$ century BC denarius of M. Calidius, Q. Metellus and Cn. Fulvius and a Greek Imperial issue of Tomis (Domitian), were published a long time ago, see Poenaru Bordea 19831985, 169-170. An earlier as of Vespasian was found in 1983 in the eastern sector, next to curtain wall G, yet not in a relevant stratigraphic position, see Talmațchi 2005-2006, 334, no 20.

7 Šelov 1986, 396-397.

8 The area of the supposed rubbish pit was used for dwelling in the $11^{\text {th }}$ century.

9 The mentioned storage pit was previously excavated in 1950's by a team lead by Grigore Florescu. See Florescu et al. 1959, pl. I (dwelling no. 6, partially superposing an earlier destroyed dwelling to which actually the storage pit belonged).
} 
'Rock of Capidava' ${ }^{10}$. This proves the fact that our context no. 6 is the earliest context excavated so far at Capidava, however it does not exclude the existence of a previous timber phase erased at the construction of the subsequent stone one. Inside Barracks no. 2 the floor was removed during the excavation in the same intent to find the timber phase. One thing is certain, as it can be seen in Pl. III/2, underneath the floor of the barracks there is a layer of grey earth mixed with burned organic material, alas no artefact whatsoever. Extensive excavations on this context will eventually shed light on this issue and hopefully will reveal a 'context no.7', the much sought-for 'timber phase' from Capidava.

\section{Stratigraphy}

The general stratigraphy of the Building $\mathrm{C} 1$ is relatively simple and representative for the entire stratigraphy of Capidava. During the archaeological research the recording of the vertical stratigraphy of the site, and implicitly of the finds and complexes, was made by defining several archaeological contexts (Fig. 1). Thus, we have established six different contexts, as follows:

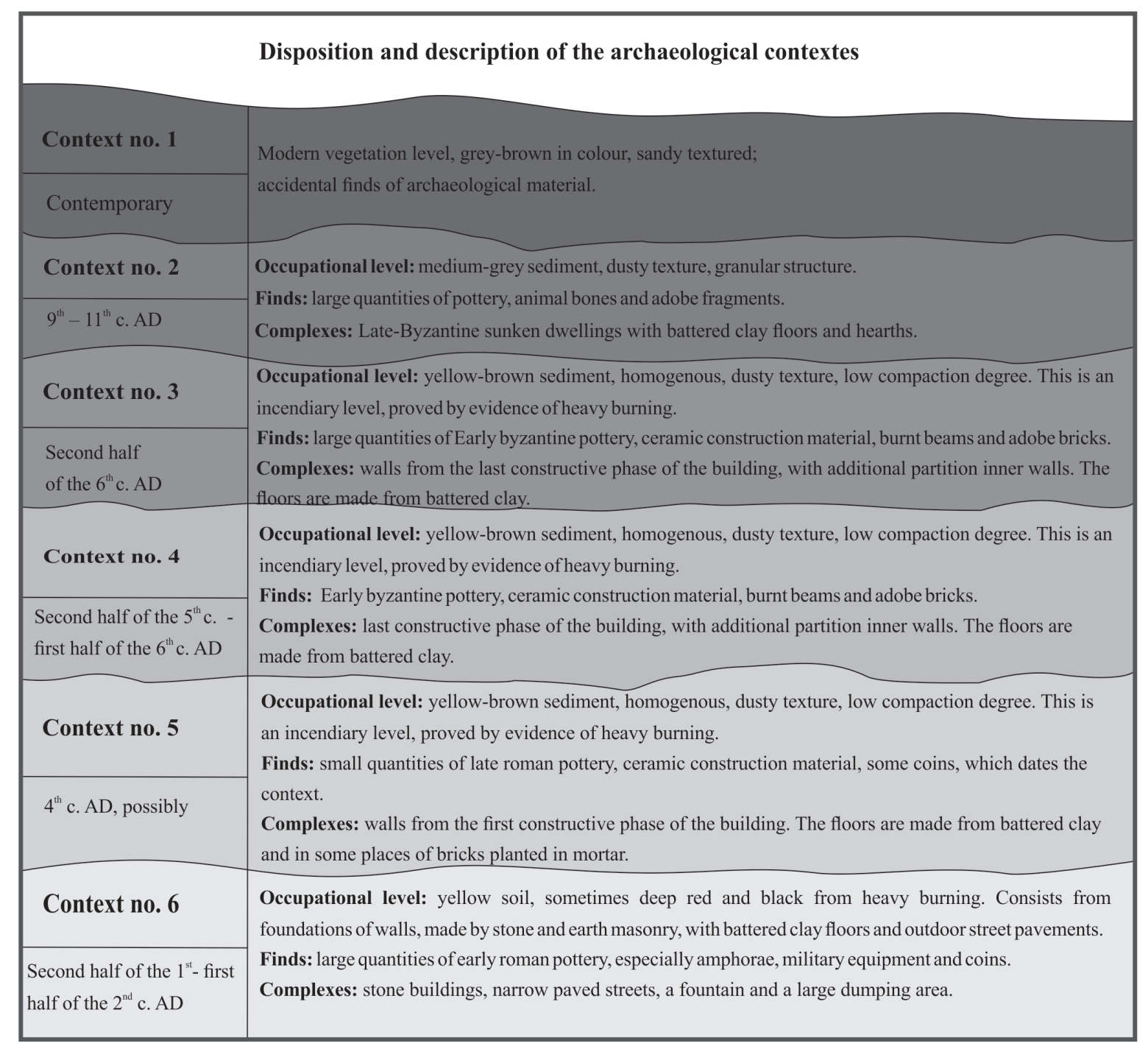

Fig. 1. The Stratigraphy of Capidava, graphical representation.

The military equipment presented in this study was collected from the last (first in chronological order) Roman contexts discovered, namely Context No. 6.

10 The fort at Capidava was erected on a large limestone cliff on the right bank of the Danube, guarding the nearby ford of the river. 


\section{Artefacts}

Trifid pendants and phalera. The first ensemble was discovered inside Barracks No. 1 near the western wall on the floor (Pl. II) during the 2016 campaign. This type of artefact is a junction loop phalera ${ }^{11}$ with a trifid pendant ${ }^{12}$ attached to it (Fig. 2). The pendant has the shape of an oak leaf with two lateral terminals stylized as acorns. The surface of the decorum is represented by stylized grapevine leafs made by niello decoration technique. The phalera was decorated in the same technique but with a simpler design, namely a rosette. Both objects were made from copper alloy and plated in silver. Today little remains from the decorum, only small fragments of decoration and scraps of silver-plating, enough to indicate, combined with the study of the analogies, how the entire decoration really looked like. Both phalera and pendant are still connected together from a loop holder on the back-side of the phalera.

From functional perspective, the phalera belongs to the type Bishop $2 \mathrm{~d}^{13}$, the pendant on the other hand belongs to the type Bishop $1 \mathrm{c}^{14}$. The loops on the back of the phalera were used to strap the garment on a leather girdle from the harness located on the chest area (Pl. V). Usually, there was more than one such adornments on a single harness belt. The Doorwerth ${ }^{15}$ find shows (Pl. VI) several small phalera and pendants on both sides of the chest and a larger set in the center. Besides the visual effect there must have been a phonic effect also, a sort of jingle, which multiplied to a few dozen horses would have been quite impressive
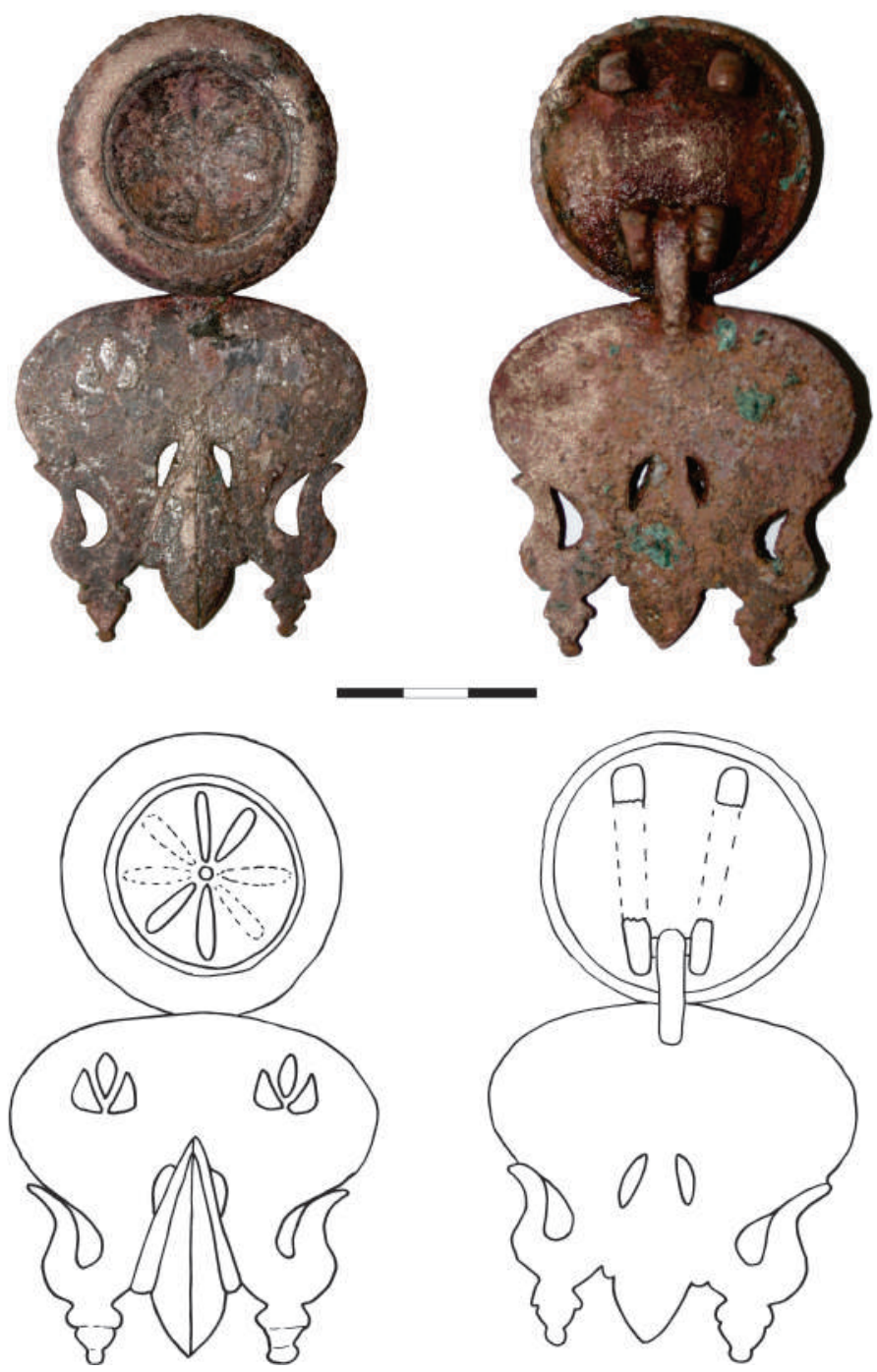

Fig. 2. Trifid pendant and phalera from Capidava (2016). (Pl. XI).

The piece was discovered in Barracks no. $2^{16}$, a long and relatively narrow building, belonging to the first archaeological context from Capidava, a building almost entirely demolished during the construction of the Late Roman Headquarters (Pl. II). Underneath the foundations of the Headquarters, there were uncovered, among other things, two buildings (Barracks no. 1 and Barracks no. 2), built side-by-side, $5 \mathrm{~m}$ in width and more than $10 \mathrm{~m}$ in length ${ }^{17}$. They were built near a street paved with stone. The few finds inside those two buildings are military objects and fine ware pottery.

Some of the most notable analogies (especially for the pendant) were discovered at Magdalensberg and Wroxeter ${ }^{18}$,

\footnotetext{
1 Diameter: $4.5 \mathrm{~cm}$.

12 Length: $5.7 \mathrm{~cm}$; Width: $5.8 \mathrm{~cm}$.

13 Bishop 1988, 139, fig. 41.

14 Bishop 1988, 142, fig. 43.

15 Holwerda 1931, fig. 11 (after Nicolay 2007, 186, fig. 5.11)

16 The exact function of the building is still under discussion, we are still processing the information from these contexts. The working hypothesis is that it served as military barracks.

17 Not being the focus of the research they were not entirely excavated, namely their north-eastern side is still not researched.

18 Bishop and Coulston 2006, 120, fig. 70, nos. 3, 8.
} 
also at Doorwerth ${ }^{19}$, Rottweil ${ }^{20}$, Xanten ${ }^{21}$, Gardun (Tilurium, Croatia) ${ }^{22}$, Biatorbágy ${ }^{23}$ (Hungary), Singidunum ${ }^{24}$, Dura Europos ${ }^{25}$. In Dacia there is an almost perfect analogy at Prejmer ${ }^{26}$ and an analogy for the phalera at Sarmizegetusa Regia ${ }^{27}$. The items are dating from the middle of the first century, based on analogies from other Roman military contexts ${ }^{28}$.

\section{A second set of phaler $\boldsymbol{~}^{29}$ with trifid pendant ${ }^{30}$} (Fig. 3) was discovered in the 2018 campaign, situated at around $10 \mathrm{~m}$ to the east from the first one (Pl. II). This second garment was in close proximity to a small javelin head, very poorly preserved. The phalera is well preserved, but the pendant is missing its lower half. Both the phalera and the pendant are identical with the first set, therefore could date from the same time with the same analogies. Being a more recent find the phalera and pendant are still in process of restoration and conservation. As it can be observed at Doorwerth, the pendants from a single set are almost identical in size, type and execution (P1. IV). The ones discovered at Capidava have slight differences in size; nevertheless, they belong to the same typology so one cannot exclude any option.

The production of these type of fittings would have been a complex process carried out by highly specialized personnel. J. Oldenstein argues that the silvered and nielloed fittings
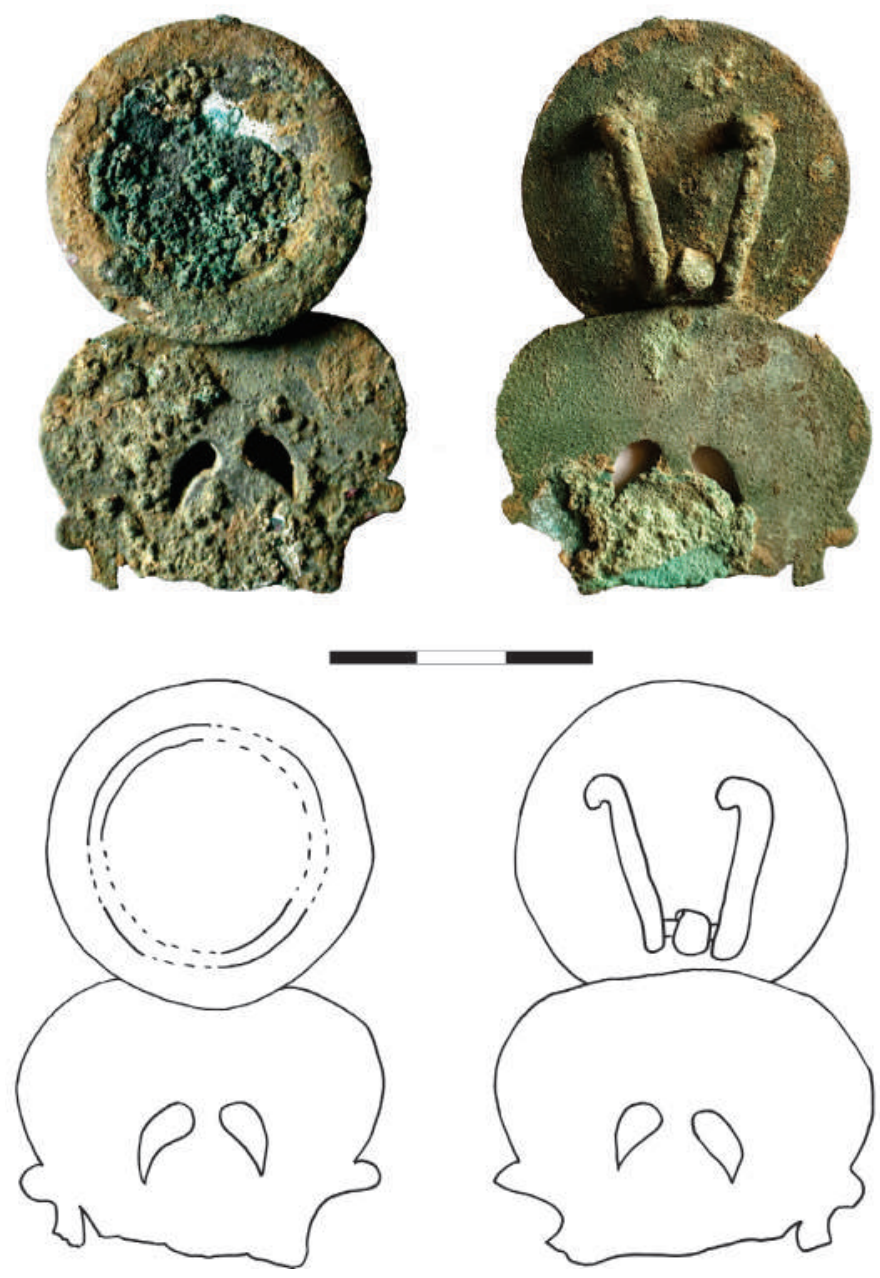

Fig. 3 Trifid pendant and phalera from Capidava (2018). were produced in large military workshops from Italy and/or Gaul, no later than the middle of the Flavian period ${ }^{31}$. The method used in the production of the fittings was the so-called lost wax method, with one-time molds, which made them reasonably expensive and sought after ${ }^{32}$.

Lunate pendant. The symbol of the crescent moon is widely spread across history, from prehistory to present day; the crescent (lunula) is a very powerful symbol, which represented throughout the antiquity the moon and femininity, complementary to the phalera, which represented the sun and masculinity ${ }^{33}$. For the Roman horsemen the lunula was very important, since this type of garment is found in many sites and very different contexts for both horses and men. The reliefs from Trajan's Column depict numerous horses wearing lunula pendants hanged from

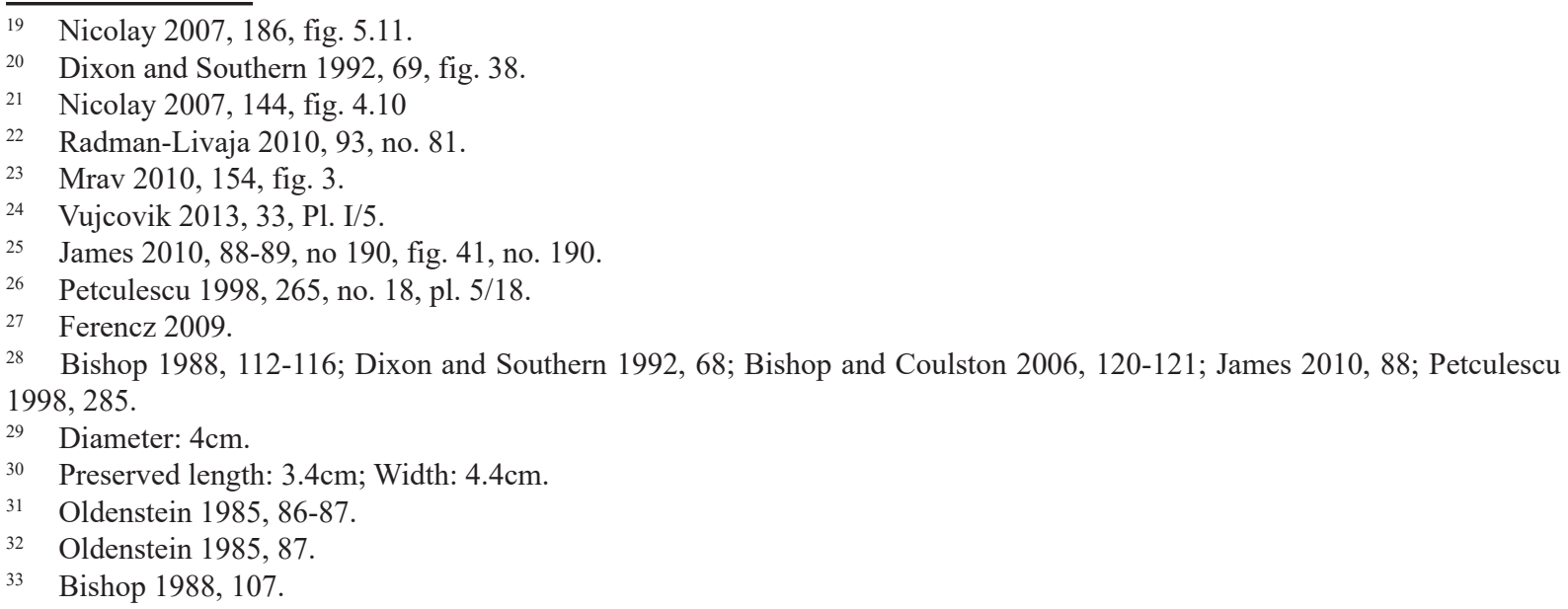




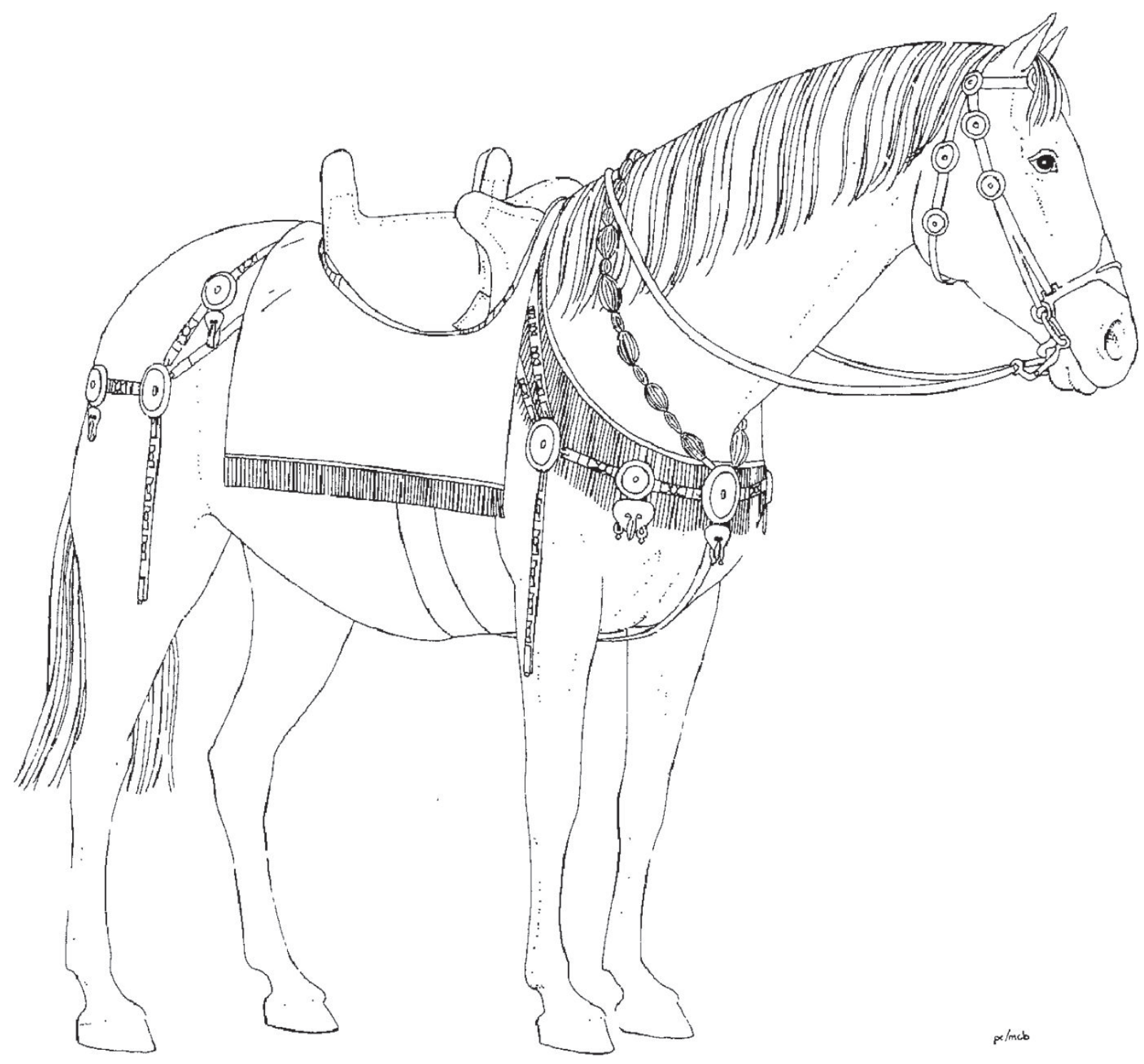

Fig. 4. Typical Flavian harness (Bishop 1988, 114, fig. 30)
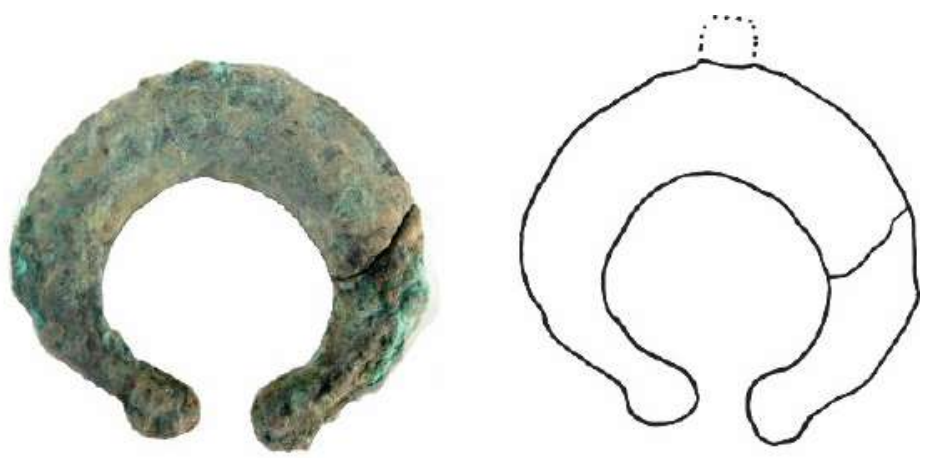

Fig. 5. Lunate pendant (lunula) from Capidava. 
phalerae and pined to their peytralls or to other parts of their equipment (Pl. III). The Capidava lunate pendant ${ }^{34}$ is a relatively large bronze piece, somewhat poorly preserved. It belongs to the type Bishop $9 \mathrm{~g}^{35}$, arguably the most simple type. Unlike the lunular pendants made for human wear, this one is one sided, meaning that it has a front and a back, therefore used for adorning the horse equipment.

As previously mentioned, the lunate motif was widely spread all-over the Roman world, therefore many analogies can be found for the one in Capidava, such as those from Wiesbaden, Zugmantel, Aalen, Osterburken, Straubing and Langendiebach ${ }^{36}$ (Germany), Beuningen (Netherlands) ${ }^{37}$, and Dura Europos ${ }^{38}$ in Syria.

\section{„D” shaped belt buckle.}

The Roman military belt, cingulum militare (militiae), was most probably called a balteus ${ }^{39}$ during the first two centuries A.D. when it also indicated the status of its bearer. Although the décor of the belt was very different from

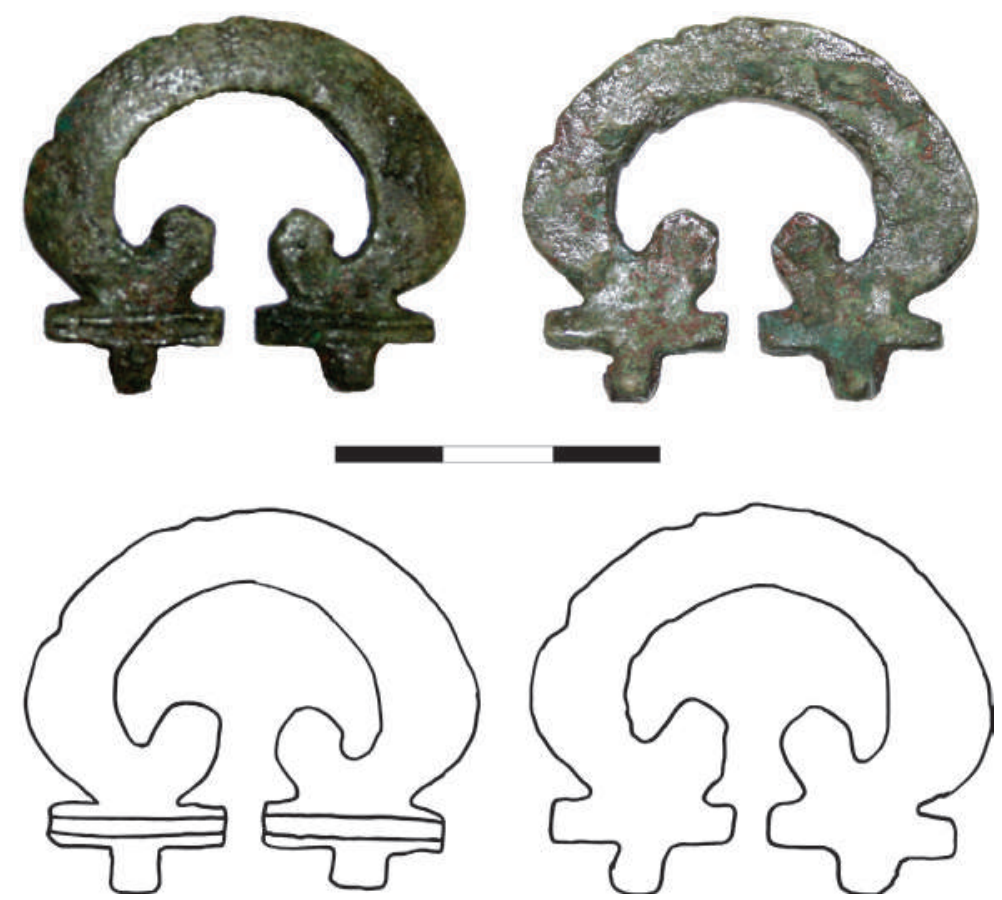

Fig. 6. „D” shaped belt buckle from Capidava. one piece to another, the belt buckles were usually $\mathrm{D}$ shaped with internal volutes. These buckles were attached to a bronze plate; which was then attached to the leather belt itself. Commonly the tongue of this type of belt buckle was of the fleur de lys type, although, in the absence of the tongue one can only speculate.

The buckle from Capidava ${ }^{40}$ has a common form, a well-known typological evolution, and is exceptionally well preserved. The loop of the buckle is wedge-shaped in section and ends in two inward curved lobes. There are two basal bars each with a broad transverse groove above each of the hinge loops; the only atypical characteristic of the piece is that the basal bars are not joined. The buckle was used to fasten the waist belt of the soldier, and it is usually found in connection with both infantry and cavalry. Very close analogies were found at Roecliffe ${ }^{41}$ and Hod Hill ${ }^{42}$ in United Kingdom, Wijk bij Duurstede ${ }^{43}$ and Velsen ${ }^{44}$ in Netherlands, Wiesbaden in Germany ${ }^{45}$, Dura Europos ${ }^{46}$, Viminacium ${ }^{47}$, Tilurium ${ }^{48}$ (Gardun, Croatia) and also in Barbaricum, at Socu-Bărbătești ${ }^{49}$ (Gorj County, Romania).

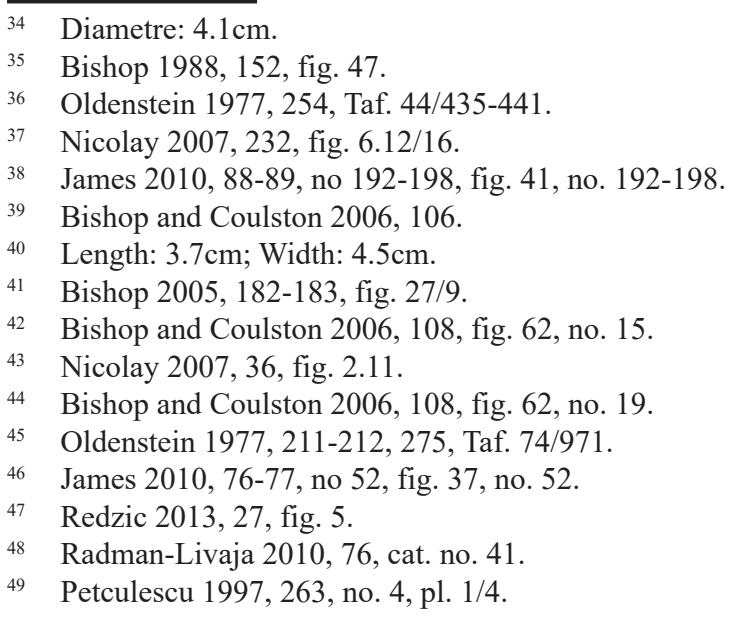




\section{Dating issues}

From all the archaeological finds discovered in the edifice in question, the fine wares pottery (vasa escaria) are the most reliable in terms of dating. The narrow dating of these artefacts offered the research team valuable dating markers for the entire context. Therefore, the rather large number of terra sigillata finds discovered in connection with the military equipment is invaluable for contextualization.

On top, the typology of the equipment in question is most relevant in terms of dating. Back in 1988 M. C. Bishop made a most compelling argument ${ }^{50}$ for the dating and the typology of the equine harness equipment. Since then all the experts in this field, without exception, adhered to his assertions and chronological typology.

If we start from the assumption that this type of pendants appeared in Magdalensberg, the form's terminus post quem is situated around $40 \mathrm{AD}^{51}$. It started to circulate during the reign of Claudius (41-54 AD) ${ }^{52}$ and increased its frequency in the decades that followed. This can be deducted from studying the sites where other similar artifacts were discovered: the vast majority are dated in the Flavian era. The trifid phalera pendants abruptly disappeared from usage from the middle of the eighth decade of the $1^{\text {st }}$ century $\mathrm{AD}^{53}$. Oldenstein separates the finds in two dating groups: the Early Flavian and Late Flavian ones ${ }^{54}$.

\section{Who used to wear them?}

The pedants were obviously accessories for horses, however, the question remains, to whom did these horses belong? Because artifacts do not mean much without a historical context, the true aim of every archaeologist is, or should be, to bring even a small contribution to the history of a place, a region, a population, etc. At Capidava during the Principate there are two military units attested, through inscriptions from the necropolis and a few brick stamps, namely: cohors (I) Ubiorum equitata and cohors I Germanorum civium Romanorum, both recruited originally from the Rhine area. The fragments of equipment presented in this paper are without exception dated in the first century $\mathrm{AD}$, therefore we consider that troopers from cohors I Ubiorum equitata may be their real owners.

The Ubian unit was probably raised under Augustus ${ }^{55}$, as cohort Ubiorum peditum et equitum, and served in the campaign led by Germanicus in $15 \mathrm{AD}$ against the rebel Arminius ${ }^{56}$. Under Tiberius the unit bears the title cohors Ubiorum equitata, as it appears on a funeral monument from Aquileia belonging to a prafectus Titus Iulius C.f. Fab. Viator ${ }^{57}$.

The Ubii warriors were brought to Moesia probably shortly after the middle of the first century AD. The troop appears on the diploma from April 28, year $75 \mathrm{AD}$, as part of the army of Moesia ${ }^{58}$, under the short title "Ubiorum", without any numeral or adjective. Another mention of this unit is on a military diploma from $97 \mathrm{AD}^{59}$, once again without numeral. The only known quarters for the troop in Moesia is the fort from Capidava, which the unit itself probably also erected.

One tile $\operatorname{stamp}^{60}(\mathrm{Pl} . \mathrm{X} / 3)$ and a funerary monument ${ }^{61}(\mathrm{Pl} . \mathrm{X} / 1)$ bear witness to its presence at Capidava, or at least this was the situation until now. However, both records are very interesting thru the background information that they offer. The tile stamp, in almost cursive writing, without numeral and with the initials VB in a ligature, is clearly indicating a very early dating. In the process of documentation of this tile stamp we uncovered a second fragment of the stamp (see pl. X/2), which at first was interpreted differently ${ }^{62}$. It turned out to be the second Cohors Vbiorum stamped tile, identical with the first one.

The inscription on the other hand is a funerary monument and belongs to a veteran of cohors I Ubiorum, namely Marcus Cocceius Vitlus. He was honorably discharged during Nerva's short reign, after faithfully serving for 28 years (most likely on September 9 ${ }^{\text {th }}, 97$ after being recruited in AD 69, in the context of the Civil War and early

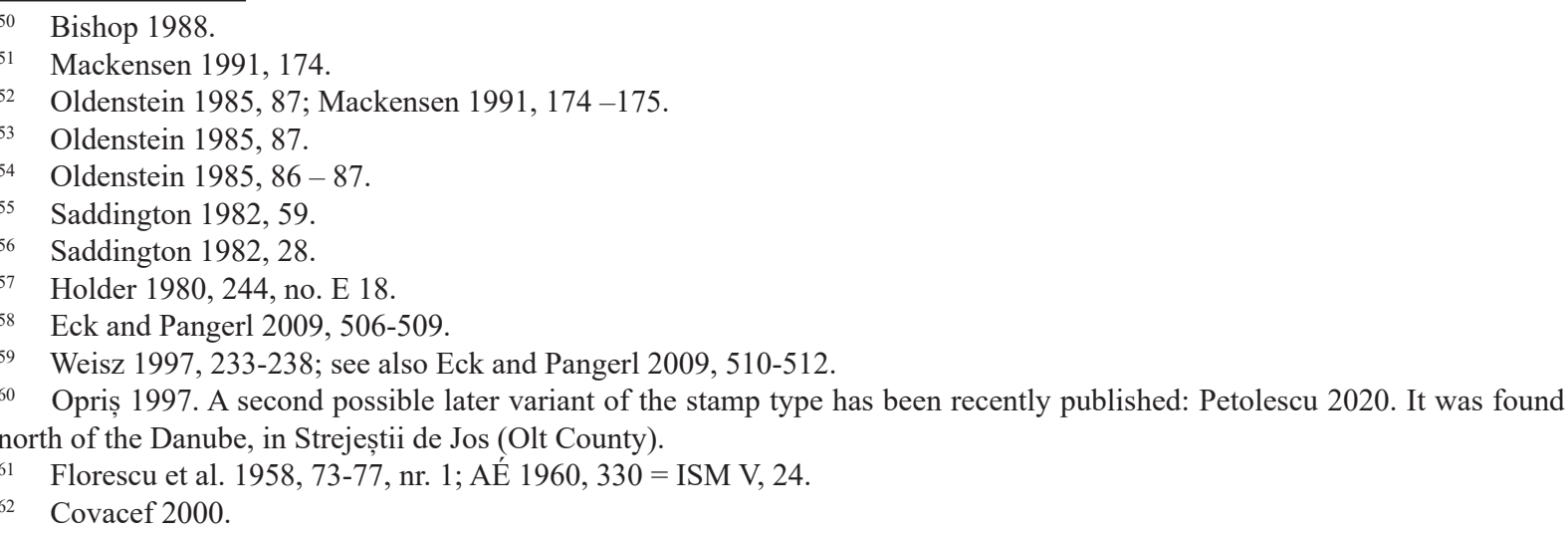


reign of Vespasian $)^{63}$. After his honorable discharge, this peregrinus of Celtic origin ${ }^{64}$ became a Roman citizen and important member of the local society at Capidava. He passed away septuagenarian, in the early part of Hadrian`s reign. One should stress here that usually the veterans remain in the provinces where they have served the most and have grown roots; therefore, we can presume that Marcus Cocceius Vitlus was stationed at Capidava at least a few years before the short reign of Nerva.

It is recorded that the unit was part of the great Trajan's army during the Dacian campaigns ${ }^{65}$, and we believe that immediately after the war the unit was (at least partially) brought back to its garrison in Capidava ${ }^{66}$. Insofar, the last known diploma to the exercitus in Moesia Inferior mentioning cohors Ubiorum is that from Sexaginta Prista, dated May 13, $105^{67}$. It probably remained here until the arrival of cohors I Germanorum (civium Romanorum), which came from Germania Superior before $121^{68}$. This other German troop remained at Capidava up to mid. $3^{\text {rd }}$ century ${ }^{69}$. As to cohors Ubiorum, it will be listed a few years later in the army of Dacia Inferior, in the Asseria diploma, dated 12 February $126^{70}$.

\section{Conclusion}

The beginnings of the Roman fort at Capidava are somewhat in obscurity, as nobody can say for sure the event or the decade in which the fort was first built. It is clear that it was erected after AD 46, yet one may assume either the early years of Vespasian, a moment linked to the making of the province of Moesia Inferior or even later, until the end of the Dacian Campaigns of Emperor Trajan. The safe assumption was to attribute the erection of the fort at Capidava to Trajan who ordered its construction as part of the effort to strengthen the Danube limes after the Dacian incursion into Moesia. Until recently there were too many stray finds from the early period of the fort and very few objects discovered in context. Nothing inside the precinct was excavated, nevertheless, published. The areas dated in the first two centuries that have been already excavated were the balneum, the harbor and the necropolis. The bathhouse (balneum) excavated thirty years ago waited until last year for publication, alas not by the original team that did the main excavation ${ }^{71}$. The harbor and the necropolis still await to be published, with no foreseeable finalization.

Our paper aims to raise an important question: wouldn't it be more logical and simple to explain that the auxiliary fort from Capidava was erected by and for cohors I Ubiorum equitata, somewhere before the making of the Province of Moesia Inferior? It would give an explanation as to where the troop of Ubians was stationed until the reign of Trajan (since it was attested in Moesia and yet no other site would claim them!). In addition, the rather early military equipment presented above, along with some other ceramic fine ware and a few coins, all dated at the middle of the first century AD, would have an obvious explanation. Even the elevated status among the local elite of some veteran families from the Ubian cohort would make more sense, since in this scenario the troop would have been at Capidava for almost half a century.

J. Oldenstein discusses in a paper form $1985^{72}$ the production of the military equipment and how the study of this topic is relevant in the historical interpretation of the archaeological context. One of the examples he offered in his paper is about the harness fittings with phalera and pendant, silvered and decorated in niello technique. The scholar argues that this type of equipment is found in the long pacified and rich provinces and in the newly conquered or in course of being conquered provinces. In „older” limes provinces the finds are already local copies of the originals usually lacking decoration. In the light of this demonstration, we are once more inclined to place the finds from Capidava in the early Flavian period. An interesting parallel to this situation is the Samia vasa ${ }^{73}$ production that near the end of the first century AD loses in quality but gains in quantity as a result of a production shift from the Gallic and Italic centers which lose ground in favor of the local production ${ }^{74}$.

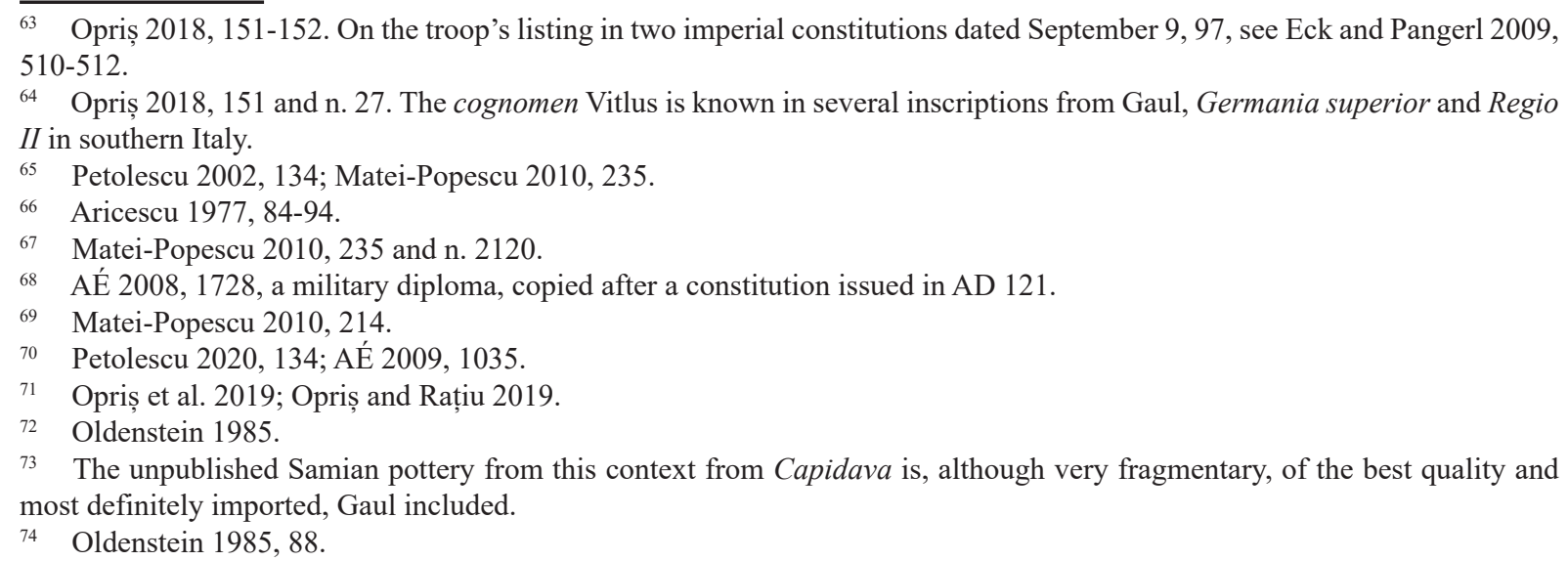


It is then possible, if not probable, that Capidava was one of the first forts erected in the early years of Vespasian and manned by cohors Ubiorum equitata. The troop's earliest mention within the army of Moesia in the diploma given in $75 \mathrm{AD}$ fits with this assumption and one should accordingly imagine an initial Flavian "Holzlager" at Capidava. Given the $3^{\text {rd }} 4^{\text {th }}$ century a fundamentis reconstruction of the fort we should point out that such an earth and timber phase would be extremely difficult to identify in any archaeological context. One should finally add that supplementary arguments to Vespasian' construction activities by the Lower Danube are available elsewhere in Dobrudja, but we shall leave this important topic to a later, thorough analysis.

Our theory regarding a Flavian Capidava will have to wait for being checked and confirmed, after the analysis of the entire material from the earliest context from Capidava, including the numismatic finds. This supposition makes sense if we are to take into consideration the conversion of the local dava - an important "Machtzentrum" in Getic times and possibly also one of the Thracian strongholds in early $1^{\text {st }}$ century AD. Florian Matei-Popescu has convincingly demonstrated in two different contributions the whole $1^{\text {st }}$ century history of the land and the subtle takeover and adaptation from Thracian strategiae to Roman fortresses and territoria, such as territorium Capidavense. ${ }^{75}$ The succeeding Roman Capidava kept being an important crossing point of the river with a welldocumented customs statio $^{76}$, and controlled a large agricultural territory, with many vici, villae rusticae and local communities, quite expressive according to epigraphic sources ${ }^{77}$.

\section{ABREVIATIONS}

AÉ

ISM V
L`Année Épigraphique. Revue des publications épigraphiques relatives à l’antiquité romaine, Paris, 1888-.

Em. Doruțiu-Boilă, Inscriptiones Scythiae Minoris, V: Capidava-TroesmisNoviodunum, București, 1980.

\section{BIBLIOGRAPHY}

Bărbulescu, M. 2001. Viața rurală în Dobrogea romană (sec. I-III p. Chr.). Constanța: Muzeul de Istorie Națională și Arheologie Constanţa.

Bishop, M.C. 1988. Cavalry equipment of the Roman Army, in the 1st century A. D., in Coulston, I. C. (ed.) Military Equipment and the Identity of Roman soldiers. Proceedings of the Fourth Roman Military Equipment Conference. BAR Int. Series 394: 67-195. Oxford: BAR Publishing.

Bishop, M.C. (with contributions from: Allen, D., Boghi, F.,Brickstock, R., Coulston, J. C. N., Dickinson, B., Dodge, H., Dore, J. N., van Driel-Murray, C., Gidney, L. J., Hartley, K., Huntley, J. P., McDonnell, G., MacLean, P. and Padley, T. G.). 2005. A New Flavian Military Site at Roecliffe, North Yorkshire. Britannia 36: 135-223.

Bishop, M. C. and Coulston, J. C. N. 2006. The Roman Military Equipment: from the Punic Wars to the fall of Rome, Second Edition. London: Oxbow Books.

Covacef, Z. 2000. Cohors I Germanorum à Capidava, in Army and Urban Development in the Danubian Provinces of the Roman Empire. Proceedings of The International Symposium - Alba Iulia, 8th-10th october 1999, Muzeul National al Unirii Alba Iulia = Bibliotheca Musei Apulensis XV: 286-291. Alba Iulia: Muzeul National al Unirii Alba Iulia.

Dixon, K. R. and Southern, P. 1992. The Roman Cavalry: from the first to the third century AD. London: Routledge. Eck, W. and Pangerl, A. 2009. Moesia und seine Truppen II, Neue Diplome für Moesia, Moesia Inferior und Moesia Superior. Chiron 39: 505-589.

Ferencz, I. V. 2009. Despre o faleră de bronz descoperită la Sarmizegetusa-Regia. Terra Sebus - Acta Museii Sabesiensis 1: 63-72.

\footnotetext{
Matei-Popescu 2017; Matei-Popescu 2018.

Opriş and Rațiu 2016.

Bărbulescu 2001, 104-112, 184-188.
} 
Florescu, R. 1975. Date noi cu privire la cronologia Capidavei romane tîrzii. Pontica 8: 361-372.

Florescu, Gr., Florescu, R. and Diaconu, P. 1958. Capidava. Monografie archeologică, vol. I. Bucharest: Editura Academiei RPR.

Florescu, Gr., Florescu, R., Anastasiu, Fl., Vâlceanu, D., Mateescu, T., Teodorescu, D. and Munteanu, P. 1959. Săpăturile arheologice de la Capidava. Materiale și Cercetări Arheologice 6: 617-627.

Holder, P. A. 1980. Studies in the Auxilia of the Roman Army from Augustus to Trajan. BAR Int. Series 70. Oxford: BAR Publishing.

James, S. 2010. Excavations at Dura Europos 1928-1937. Final Report VII: The Arms and Armour and other Military Equipment, Second Edition. Exeter: Short Run Press.

Mackensen, M. 1991. Frühkaiserzeitliches Pferdegeschirr aus Thamusida (Mauretania Tingitana) - Evidenz für eine Garnison ?. Germania 69: $166-175$.

Matei-Popescu, F1. 2010. The Roman Army in Moesia Inferior. The Center for Roman Military Studies 7. Bucharest: Conphys Publishing House.

Matei Popescu, F1. 2017. Ovid at Tomis: the Early History of the Left Pontus under the Roman Rule, in Civiltà Romana. Rivista pluridisciplinare di studi su Roma antica e le sue interpretazioni IV: 17-25.

Matei Popescu, Fl. 2018. The Thracian strategiae in Scythia Minor, in Boteva-Boyanova, D., Delev, P. and Tzvetkova J. (eds.) JUBILAEUS VII. Society, Kings, Gods. In memoriam professoris Margaritae Tachevae: $107-$ 118. Sofia: St Kliment Ohridski University Press.

Mráv, Z. 2010. Fémberakással díszített kora császákori phaleracsüngő Biatorbágyról (Pest megye, Magyarország) / Roman trifid phalera pendant with metal inlay decoration from Biatorbágy (Pest County, Hungary), in Kvassay J. Szerk (ed), Évkönyv és jelentés a Kulturális Örökségvédelmi Szakszolgálat 2008. évi feltárásairól. / 2008 Field Service for Cultural Heritage Yearbook and Review of Archaeological Investigations: 139-162. Budapest: Hungarian National Museum.

Nicolay, J. 2007. Armed Batavians - Use and Significance of weaponry and horse gear from non-military contexts in the Rhine Delta (50 B.C. to A.D. 450). Amsterdam Archaeological Studies II. Amsterdam: Amsterdam University Press.

Oldenstein, J. 1977. Zur Ausrüstung römischer Auxiliareinheiten. Bericht der Römisch- Germanischen Kommission 57/1976: 49-284.

Oldenstein, J. 1985. Manufacture and supply of the Roman army with bronze fittings, in Bishop, M. C. (ed.) The Production and Distribution of Roman Military Equipment. Proceedings of the Second Roman Military Equipment Research Seminar. British Archaeological Reports, International Series 275: 82 - 94. Oxford: BAR Publishing.

Opriş, I.C. 1997. O nouă mărturie epigrafică privitoare la staţionarea cohortei I Ubiorum la Capidava / Ein neues Zeugnis bezüglich des Aufenthalts der Cohors I Ubiorum, in Capidava. Studii și Cercetări de Istorie Veche și Arheologie 48/3-4: 277-281.

Opriş, I. C. 2006. Fortificarea frontierei dobrogene a Moesiei Inferioare în preajma războaielor daco-romane, in Țentea, O. and Teodor, E. S. DACIA AVGVSTI PROVINCIA. Crearea provinciei, Actele simpozionului desfăşurat în 13-14 octombrie 2006 la Muzeul Naţional de Istorie a României: 237-248. Bucharest: Editura Cetatea de Scaun.

Opriş, I. C. 2018. Trajan et ses dédicaces dans la Mésie Inférieure. Activité constructive civile et militaire selon le dossier épigraphique, in Petolescu, C. C., Galinier M. and Matei-Popescu Fl. (eds.) DIVUS TRAIANUS. Travaux du Colloque International de Drobeta - Turnu Severin, 16-17 juin 2017, Muzeul Regiunii Porților de Fier Drobeta - Turnu Severin: 147-161. Bucarest: Editura Academiei Române.

Opriş, I. C. and Raţiu, Al. 2016. Roman customs station from Capidava. Statio for publicum portorii Illyrici in the $2^{\text {nd }}$ century AD and a hypothetical model for interactions with Barbaricum in the 4th century AD, in Bârcă, V. (ed.) Orbis Romanus and Barbaricum. The Barbarians around the Province of Dacia and their Relations with the Roman Empire = Series Patrimonium Archaeologicum Transylvanicum vol. 14: 89-109. Cluj-Napoca: Mega Publishing House.

Opriș, I. C. and Rațiu, Al. 2017. CAPIDAVA II. Building C1 - Contributions to the history of annona militaris in the $6^{\text {th }}$ century (with contributions by: A. Gândilă, T. Ważny, Peter I. Kuniholm, Charlotte L. Pearson, Adriana Rizzo and Choi Mak). Cluj-Napoca: Editura Mega.

Opriș, I. C. and Rațiu, Al. 2019a. Roman military baths from Capidava ( $2^{\text {nd }}-3^{\text {rd }}$ century AD), in MihăilescuBîrliba L. and Spickermann W. (eds.) Roman Army and Local Society in the Limes Provinces of the Roman Empire. Papers of an International Conference, Iași, June 4th-6th, $2018=$ Pharos. Studien zur griechisch-römischen Antike 42: 263-282. Rhaden: Marie Leidorf. 
Opriş, I. C. and Rațiu, Al. 2019b. Hostes ante portas! Cercetări arheologice recente asupra turnurilor porții principale de la Capidava /Hostes ante portas! Recent archaeological research on the towers of the main gate from Capidava. Cercetări Arheologice 26: 125-155. doi: https://doi.org/10.46535/ca.26.04

Opriş, I. C., Rațiu, Al. and Duca, M. 2014. 21. Sat Capidava, com. Topalu, jud. Constanța, punct: Cetate. Capidava 2013 - sectoarele III, VI, VII intra muros. Clădirea C2/2011, via principalis, S 1/ 2004, in Cronica cercetărilor arheologice din România, Campania 2013, A XLVIII-a Sesiune Națională de Rapoarte Arheologice, Oradea, 5 -7 iunie 2014: 35-36, 270-275 = fig. 1-14. Oradea: Muzeul Țării Crișurilor.

Opriş, I. C., Rațiu, Al. and Duca, M. 2015. 19. Capidava, com. Topalu, sat Capidava, jud. Constanţa, Punctul Cetate. Sector III, VII intra-muros, în Cronica cercetărilor arheologice din România 2015. Campania 2014, A XLIX-a Sesiune Națională de Rapoarte Arheologice, Pitești, 28 -30 mai 2015, Ministerul Culturii, Comisia Națională de Arheologie - Direcția Generală Juridică și de Patrimoniu Cultural, Muzeul Județean Argeș, 2015, 47-49, 341-343 = fig. 1-6.

Opriş, I. C., Rațiu, Al. and Duca, M. 2017. Capidava - Sectorul VII intra-muros, în Cronica cercetărilor arheologice din România. Campania 2016. A LI-a Sesiune Națională de Rapoarte Arheologice, București, Muzeul Național de Istorie a României, 24-27 mai 2017, Institutul Național al Patrimoniului, 2017, 34-35 + 6 fig.

Opriş, I. C., Rațiu, Al. and Potârniche, Ti. 2018. Băile romane de la Capidava. Raport de cercetare arheologică preventivă. Cercetări Arheologice 25: 3-28. doi: https://doi.org/10.46535/ca.25.01

Petculescu L. 1998. Roman Military Equipment in Dacia in the First Century AD, in Roman, P. (ed.) Thracian World at the Crossroads of Civilizations II, Proceedings of the Seventh International Congress of Thracology, Constanța-Mangalia-Tulcea, 20-26 May 1996: 261-285. Bucharest: Institutul Român de Tracologie.

Petolescu, C. C. 2002. Auxilia Daciae. Contribuţie la istoria militară a Daciei romane. Bucharest : Editura Ars Docendi.

Petolescu, C. C. 2020. Cohors I Ubiorum. Oltenia studii şi comunicări. Arheologie-Istorie XXVII: 133-136.

Poenaru-Bordea, Gh. 1983-1985. Alte cîteva monede descoperite la Capidava. BSNR LXXVII-LXXIX: 169-176.

Radman-Livaja, I. (ed.). 2010. Nalazi rimske vojne opreme u Hrvatskoj (katalog izložbe) / Finds of the Roman Military Equipment in Croatia (exhibition catalogue). Zagreb: Stega tisak.

Rațiu, Al., Opriș, I. C. and Popescu, R. 2018. 69. Topalu, jud. Constanța. Capidava - Sectorul VII intra muros, in Cronica cercetărilor arheologice din România. Campania 2017. A LII-a Sesiune Națională de Rapoarte Arheologice, București, Muzeul Național de Istorie a Transilvaniei, Cluj-Napoca, 15-17 noiembrie 2018: 140-141. Bucharest: Institutul Naţional al Patrimoniului - Muzeul Naţional de Istorie a Transilvaniei.

Rațiu, Al., Opriș, I. C., Popescu, R. and Manea, I. 2019. 83. Topalu, jud. Constanța. Capidava - Sectorul VII (intramuros), in Cronica cercetărilor arheologice din România. Campania 2018. A LIII-a Sesiune Națională de Rapoarte Arheologice, Muzeul Național Brukenthal, Sibiu, 13-15 septembrie 2019: 223-226. Bucharest: Institutul Național al Patrimoniului - Muzeul Național Brukenthal.

Rațiu, Al., Opriș, I. C., Moței, R. I. and Manea, I. 2020. 81. Topalu, jud. Constanța - Punct: Capidava - Sectorul VII (intra muros), in Cronica cercetărilor arheologice din România. Campania 2019. A LIV-a Sesiune Națională de Rapoarte Arheologice, Muzeul Județean Buzău, 25-27 noiembrie 2020: 372-374, 377 = fig. 1. Bucharest: Institutul Național al Patrimoniului - Muzeul Județean Buzău.

Redžić, S. T. 2013. Roman Belt Sets on the Territory of Serbia from the I to the IV century. PhD Thesis. Belgrade: University of Belgrade - Faculty of Philosophy.

Saddigton, D.B. 1982. The Development of the Roman Auxiliary Forces from Caesar to Vespasian (49 B.C.-A.D. 79). Harare: University of Zimbabwe.

Šelov, D. B. 1986. Les amphores d'argile claire des premiers siècles de notre ère en Mer Noire, in Empereur, J.-Y. and Garlan, Y. (eds.) Recherches sur les amphores grecques, École Française d'Athènes - Bulletin de Correspondance Hellénique, Supplément XIII : 395-400. Athènes: Ecole française d'Athènes / Paris: Diffusion de Boccard.

Talmațchi, G. 2005-2006. Date noi privind descoperiri monetare romane imperiale din Dobrogea. Peuce (s.n.) III-IV: 331-374.

Vijcović, M. 2013. Roman Weapons and Military Equipment from Singidunum. Vesnik 40: $29-48$.

Weiß, P. 1997. Neue Militärdiplome. Zeitschrift für Papyrologie und Epigraphik 117: 227-268. 


\section{LISTA ILUSTRAṬIILOR}

\section{Figuri}

Fig. 1. Stratigrafia sitului Capidava, reprezentare grafică.

Fig. 2. Pandantiv trifid și faleră de la Capidava (2016).

Fig. 3. Pandantiv trifid și faleră de la Capidava (2018).

Fig. 4. Harnașament tipic pentru perioada dinastiei Flaviilor (Bishop 1988, 114, fig. 30).

Fig. 5. Pandantiv în formă de semilună (lunula) de la Capidava.

Fig. 6. Cataramă de centură în forma literei „D” de la Capidava.

\section{Planșe}

P1. I. 1. Provinciile romane de la Dunărea de Jos (după Matei-Popescu și Țentea 2018, 157, pl. I); 2. Castrul roman de la Capidava, băile şi necropola (desen Al. Ratiu).

P1. II. Planul săpăturilor de la Principia de epocă romană târzie, cu sublinierea (cu roșu transparent) descoperirilor de epocă romană timpurie (desen și foto Al. Rațiu).

Pl. III. 1. Ortofotoplan al clădirii comandamentului din anul 2017 (foto Dan Costea); 2. Profil prin baraca B1, se observă podeaua pe care au fost descoperite catarama și primul pandantiv trifid cu faleră (foto Al. Rațiu).

P1. IV. 1. Profil prin baraca B1 cu detaliu pe podeaua din dale de cărămidă a clădirii comandamentului și contextul nr. 6 imediat sub aceasta; 2. Detaliu cu groapa de provizii G1, vedere dinspre sud; 3. Detaliu cu profilul rezultat prin săparea gropii G1, lângă miră este zidul barăcii B1; 4. Fotografie cu groapa G1, baraca B1 și stradela pavată. (foto Al. Rațiu)

Pl. V. 1. Reprezentări pe Columna lui Traian cu cai echipați cu piese din bronz asemănătoare cu cele descoperite la Capidava (fotografie și desen Al. Rațiu); 2. Lunula pe un harnașament militar roman reprezentat pe o metopă de pe Monumentul de la Adamclisi (C) Constanța - Muzeul National de Istorie si Arheologie, foto: Ortolf Harl 2012 , download de pe http://lupa.at/21419/photos/3); 3. Exemplu de prindere a falerei pe o curea de piele (după Bishop 1988, 97, fig. 24/2).

P1. VI. 1. O analogie foarte apropiată de la Doorwert (după Nicolay 2007, 186, fig. 5.11); 2. Capidava (foto Al. Rațiu); 3. Garnitura completă descoperită la Doorwert (după Nicolay 2007, 186, fig. 5.11). Piesele de la Capidava se aseamănă ca formă şi dimensiuni cu piesele mai mici de la Doorwert.

P1. VII. Analogii pentru pandantivele trifide: 1. Xanten (după Nicolay 2007, 144, fig. 4.10; fără scară); 2. Wroxeter (după Bishop și Coulston 2006, 120, fig. 70, no. 8); 3. Prejmer (după Petculescu 1998, 282, P1. 5/18); 4. Biatorbágy (după Mrav 2010, 154, fig. 3; fără scară); 5. Rottweil (după Dixon și Southern 1992, 69, fig. 38); 6. Dura Europos (după James 2010, 89, fig. 41, no. 190).

P1. VIII. 1. Analogii pentru pandantivele trifide: Sarmizegetusa Regia (după Ferencz 2009, 69, fig. 1); 2. Rheingonheim (după Bishop și Coulston 2006, 120, fig. 70, no. 3).

P1. IX. Analogii pentru cataramă și pandantivul de tip lunula: 1. Wijk bij Duurstede (după Nicolay 2007, 36, fig. 2.11); 2. Gardun/Tilurium (după Radman-Livaja 2010, 76, cat. no. 41); 3. Roecliffe (după Bishop 2005, fig. $27 / 9$ ); 4. Hod Hill (după Bishop și Coulston 2006, 120, fig. 70, no. 8); 5. Weisbaden (după Oldenstein 1977, taf. 74/971, no. 4, pl. 1/4); 6. Velsen (după Bishop și Coulston 2006, 108, fig. 62, no. 19) ; 7 - 11. Dura Europos (după James 2010 , 89, fig. 41, no. 192-198).

P1. X. 1. Fragment din monumentul funerar al lui M. Cocceius Vitlus, veteran al trupei cohors I Ubiorum (C) Constanța - Muzeul National de Istorie si Arheologie, foto Ortolf Harl 2012, sursa: http://lupa.at/15214/photos/1); 2. Ștampilă tegulară a trupei cohors I Ubiorum (foto I. C. Opriș; desen Al. Rațiu); 3. Ștampilă tegulară a trupei cohors I Ubiorum (foto I. C. Opriș; desen după Opriș 1997, 278, fig. 1).

Pl. XI. 1 - 2. Reconstituiri grafice a diferitelor garnituri de echipament militar de cavalerie de la sfârșit de secol I început de secol II p. Chr. (C MNIT, Expo LIMES, desene P. Connely).

ALEXANDRU RATIU

National Museum of Romanian History sandu_ratiu@yahoo.com

IOAN C. OPRIȘ University of Bucharest ioan_opris@yahoo.com 


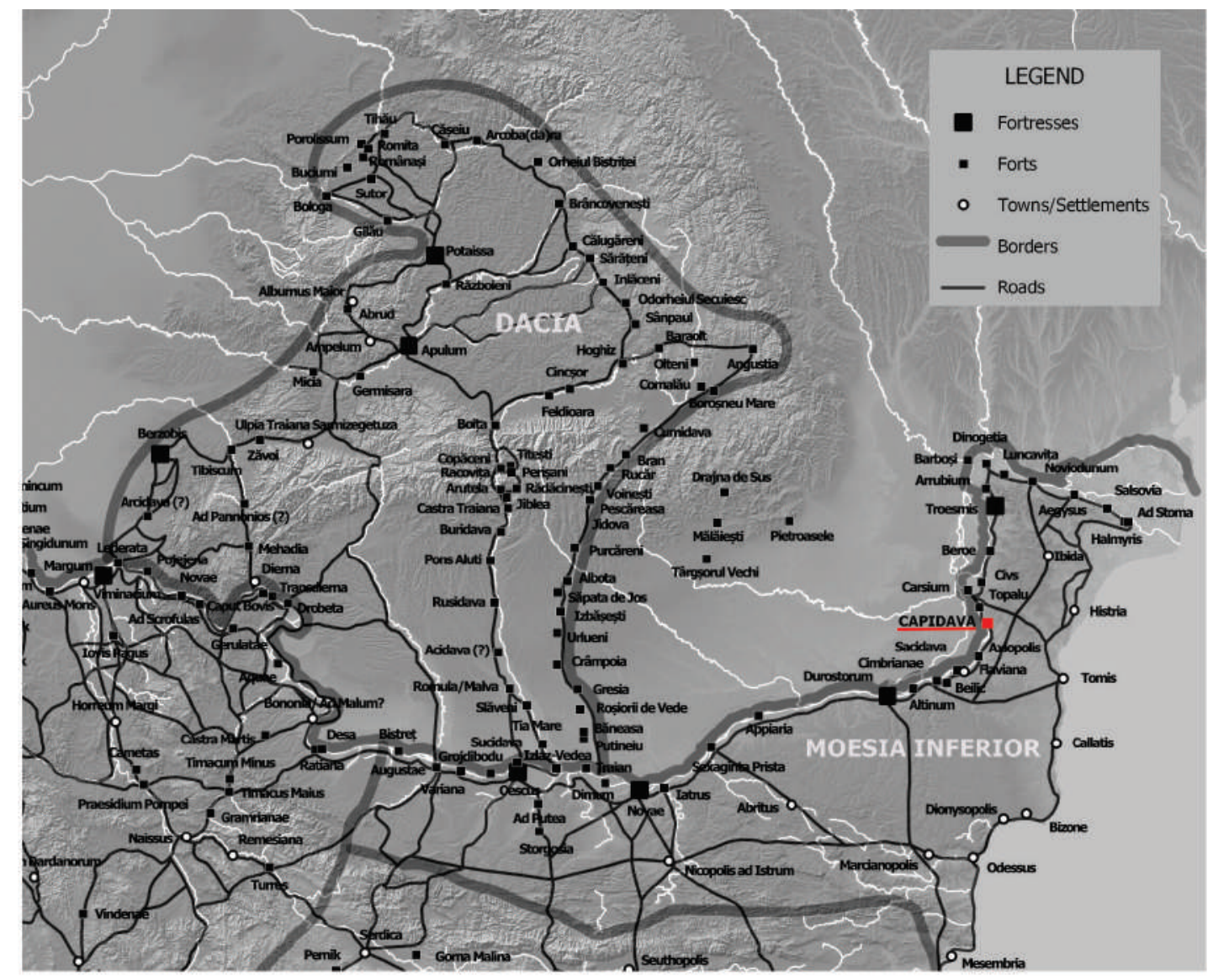

1

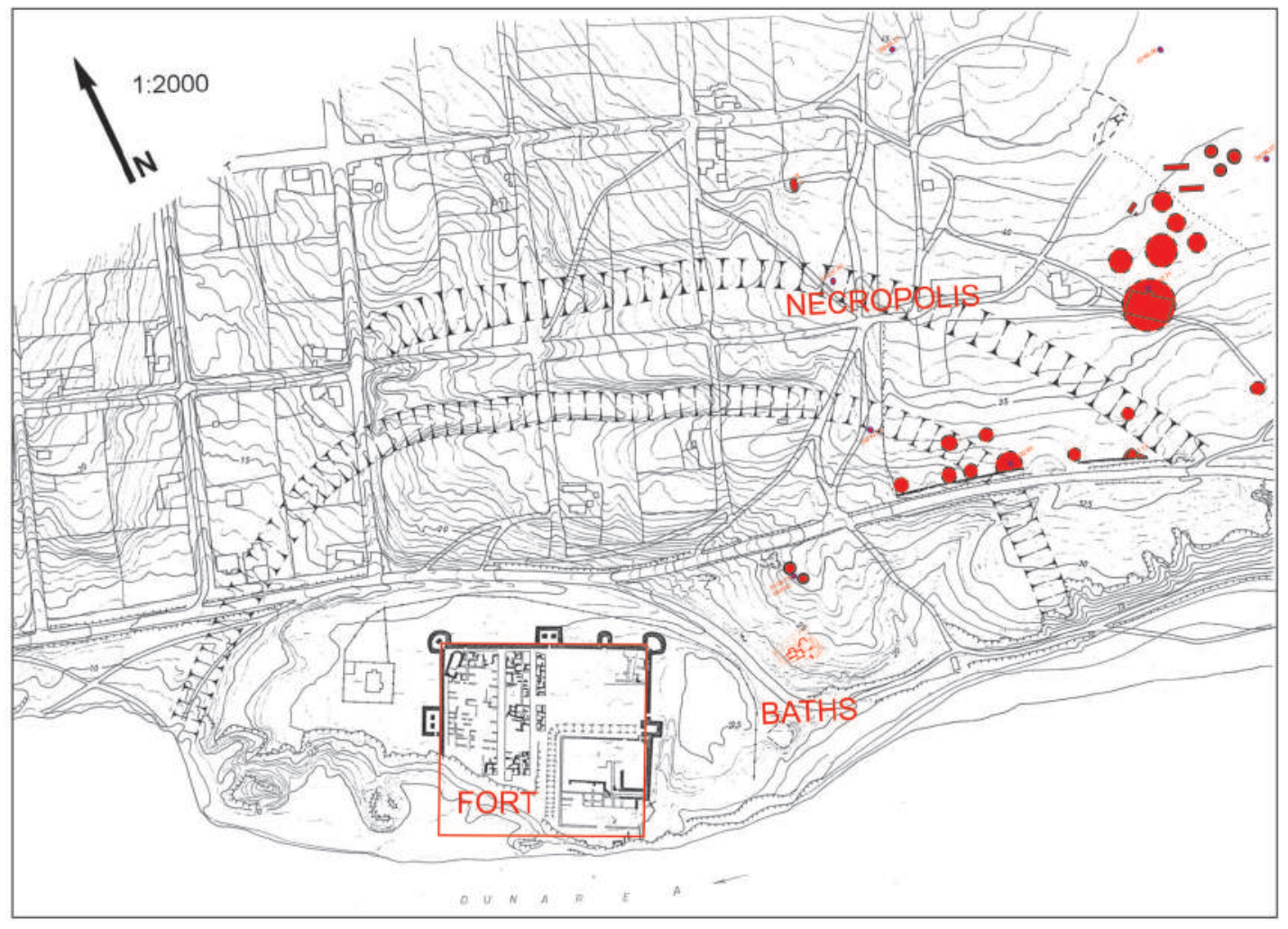

2

Pl. I. 1. Lower Danube Provinces (after Matei-Popescu and Țentea 2018, 157, pl. I); 2. Capidava Roman fort, Baths and Necropolis (after the authors). 


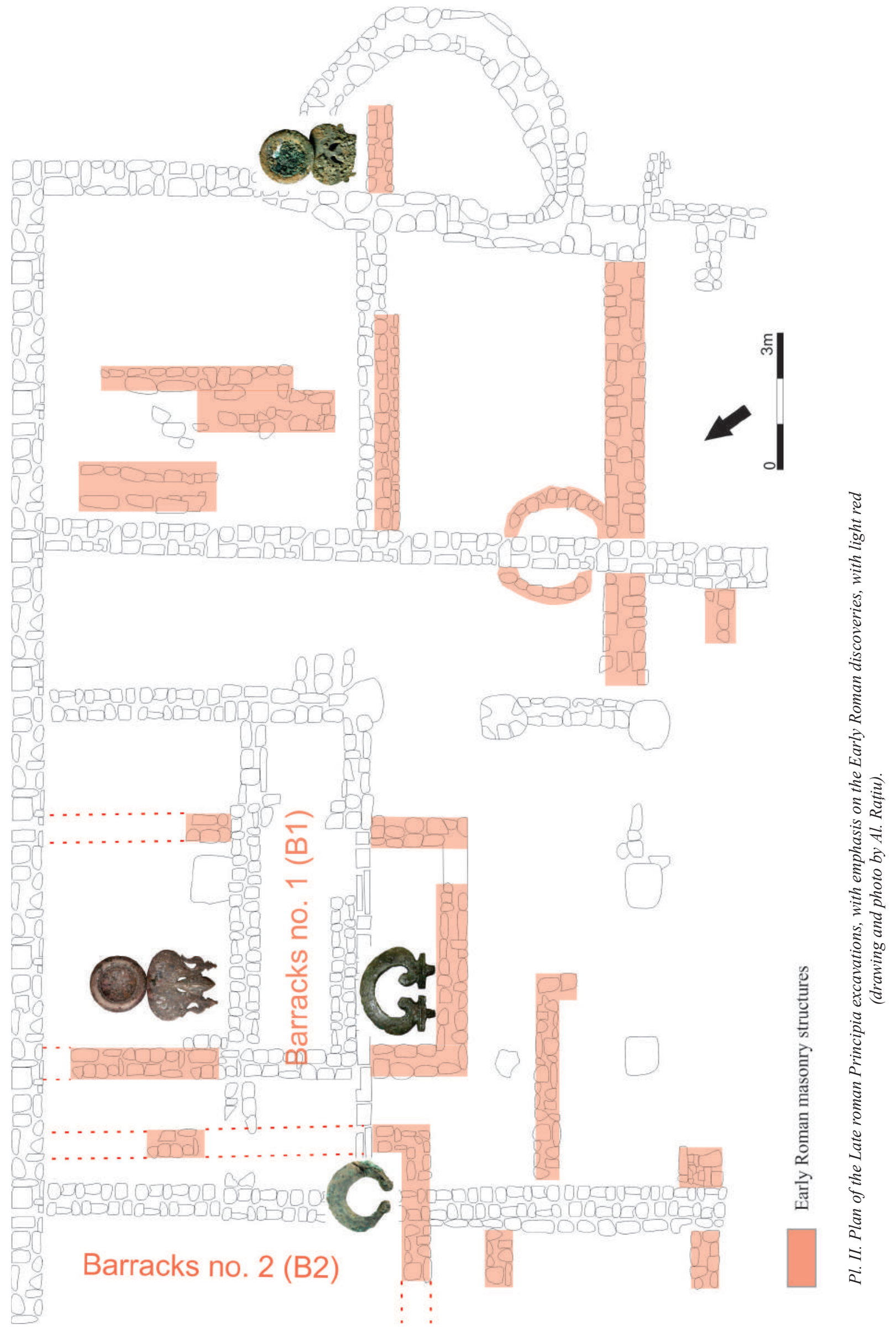



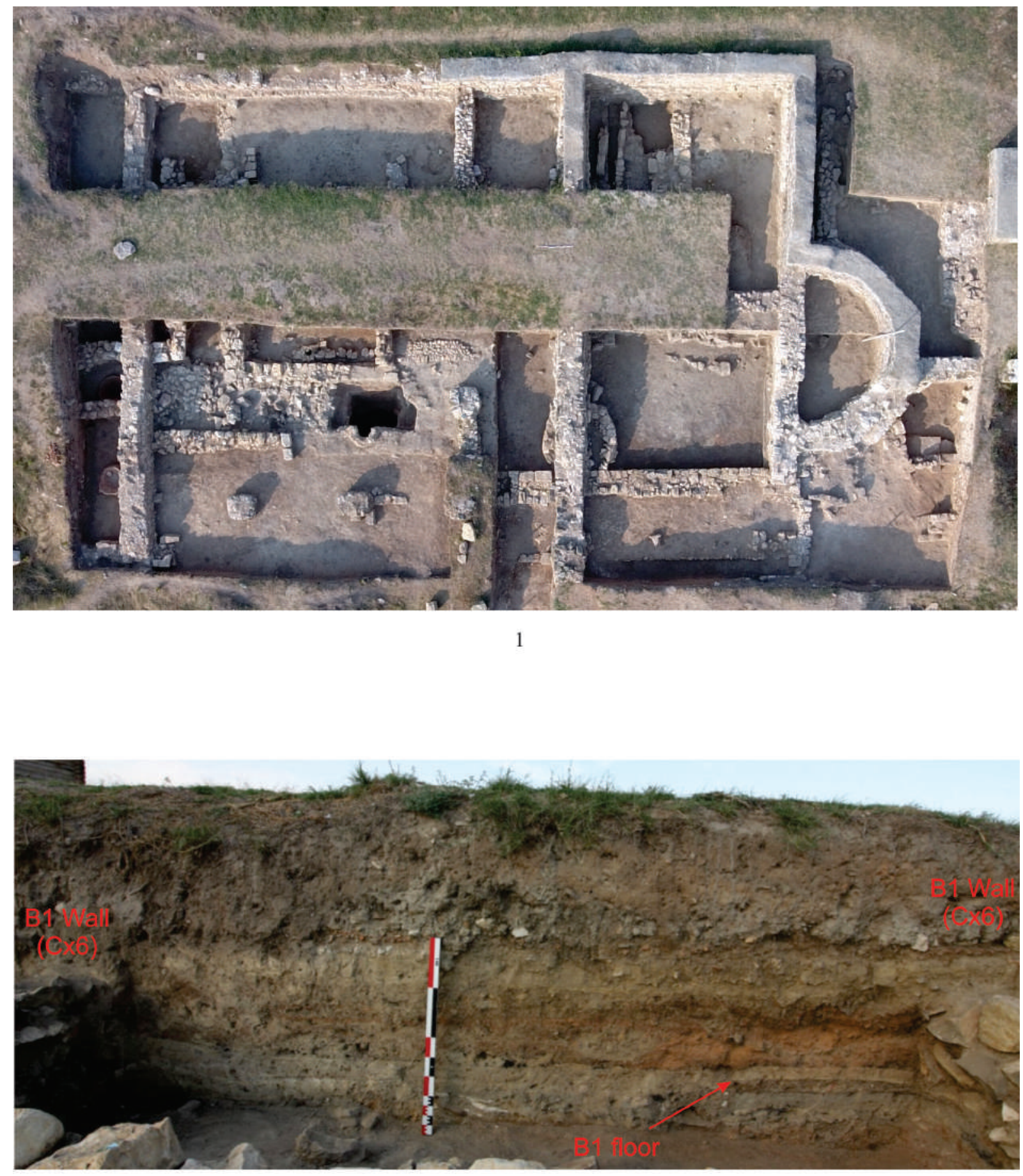

2

Pl. III. 1. Orthophotoplan of the Principia from 2017 (photo by Dan Costea); 2. Profile thru Barracks no. 1, with the floor on which the belt buckle and the first trifid pendant and phalera were found (photo by Al. Rațiu). 


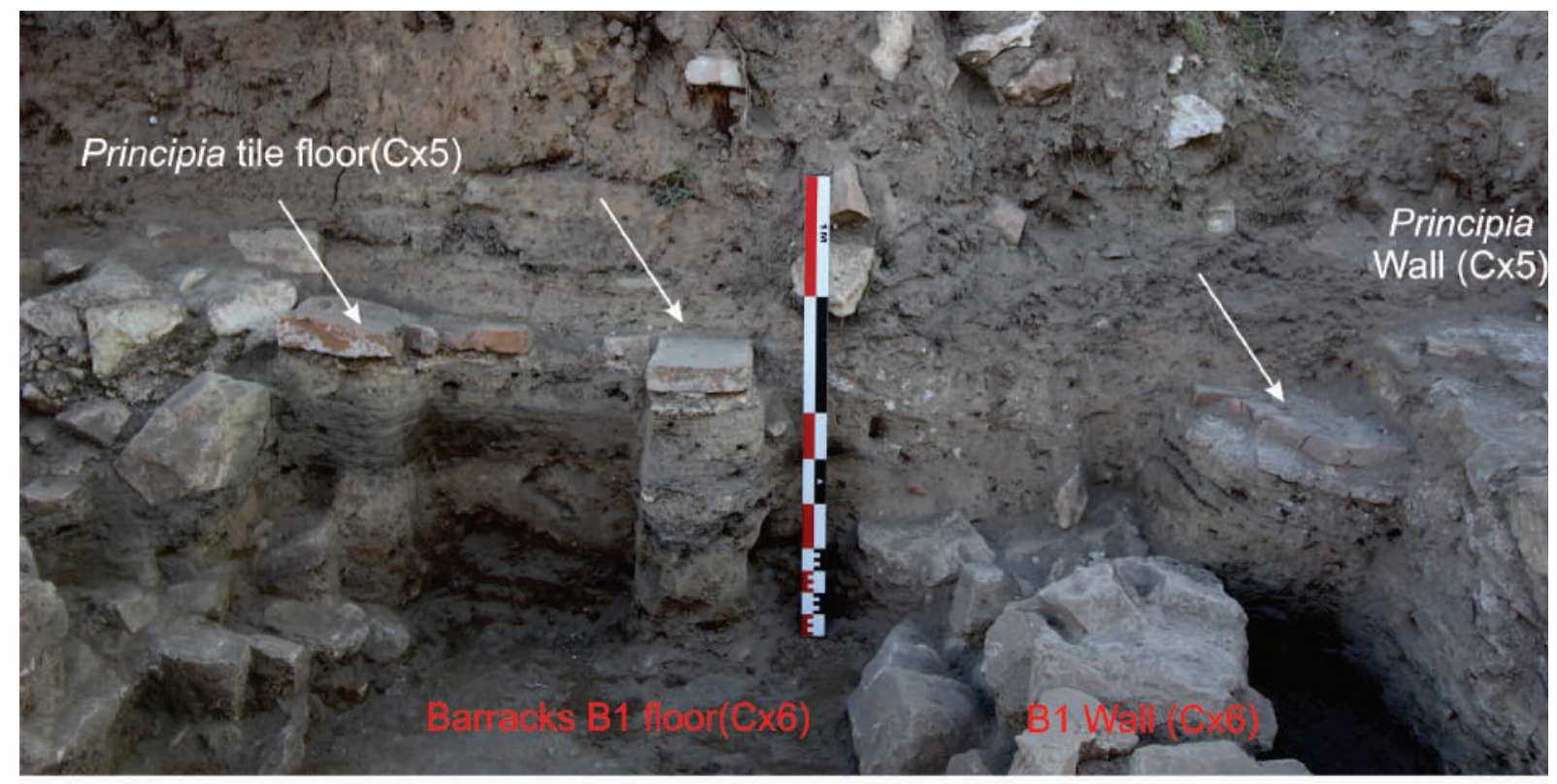

1
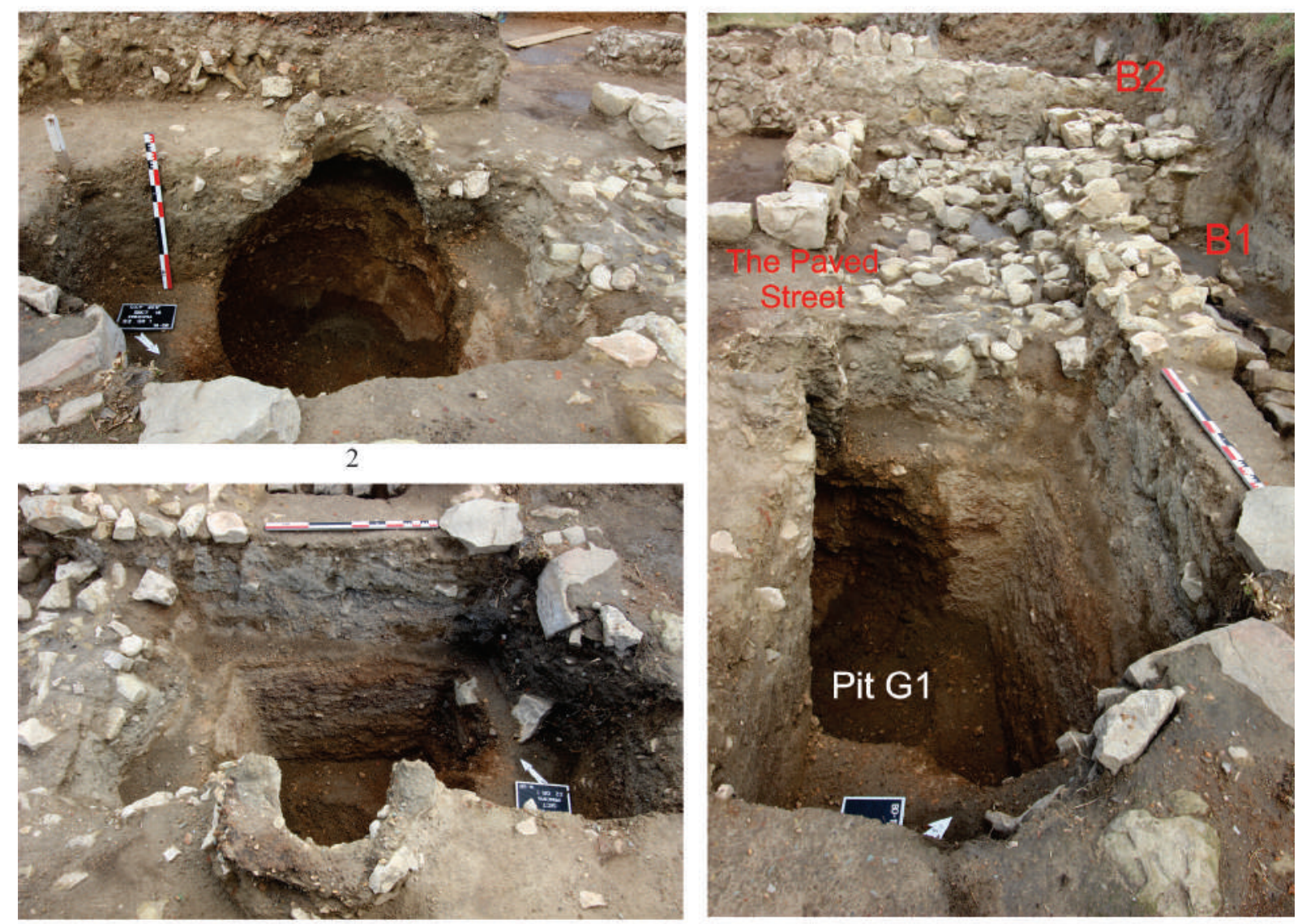

4

Pl. IV. 1. Profile thru Barracks No. 1 with detail of the tile floor of the principia and the context beneath this floor; 2. Detail with the provisions pit $G 1$, southern exposure; 3. Detail with the profile resulted from the excavation of G1, near the scale is the wall of B1; 4. Photograph wit G1 pit, B1 barracks and the paved street. (Photos by Al. Ratiiu) 

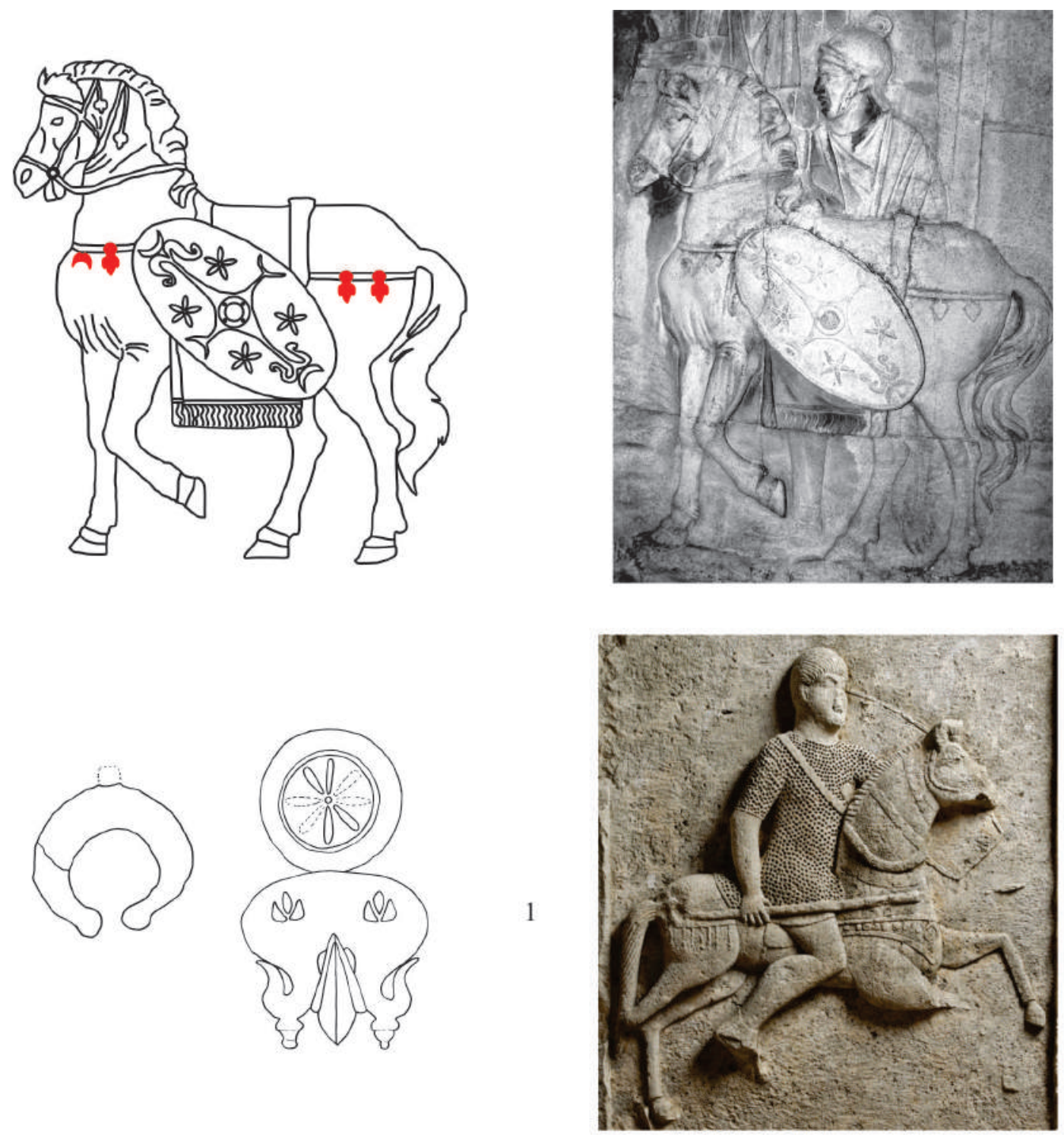

2
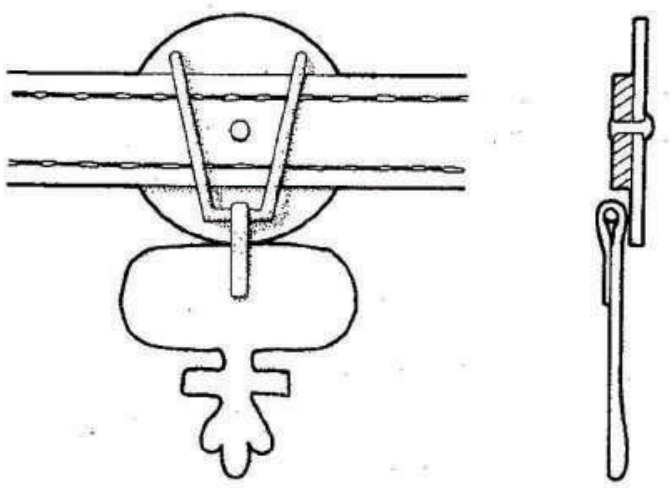

3

Pl. V. 1. Representation on Trajan's Column of horses adorned with the type of fittings discovered at Capidava (photo and drawing by Al. Rațiu); 2. Lunula on a roman cavalry equipment depicted by a metope from Adamclisi Monument (C) Constanta - Muzeul National de Istorie si Arheologie, Foto: Ortolf Harl 2012, downloaded from http://lupa.at/21419/ photos/3) 3. Example of how the phalera was fitted on a leather strap (after Bishop 1988, 97, fig. 24/2). 


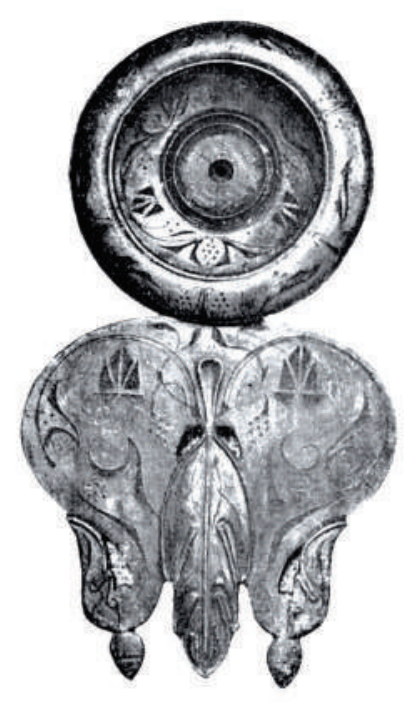

1

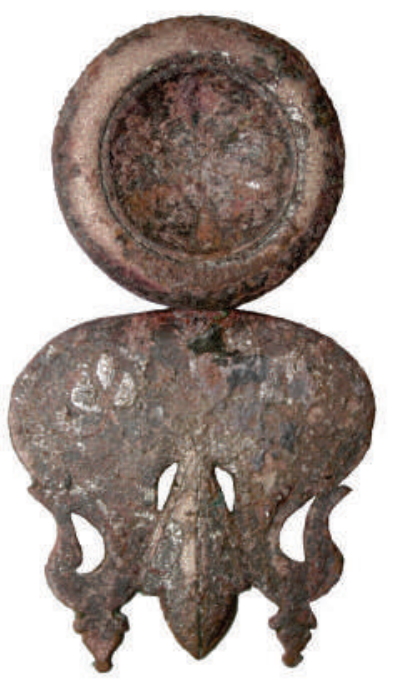

2

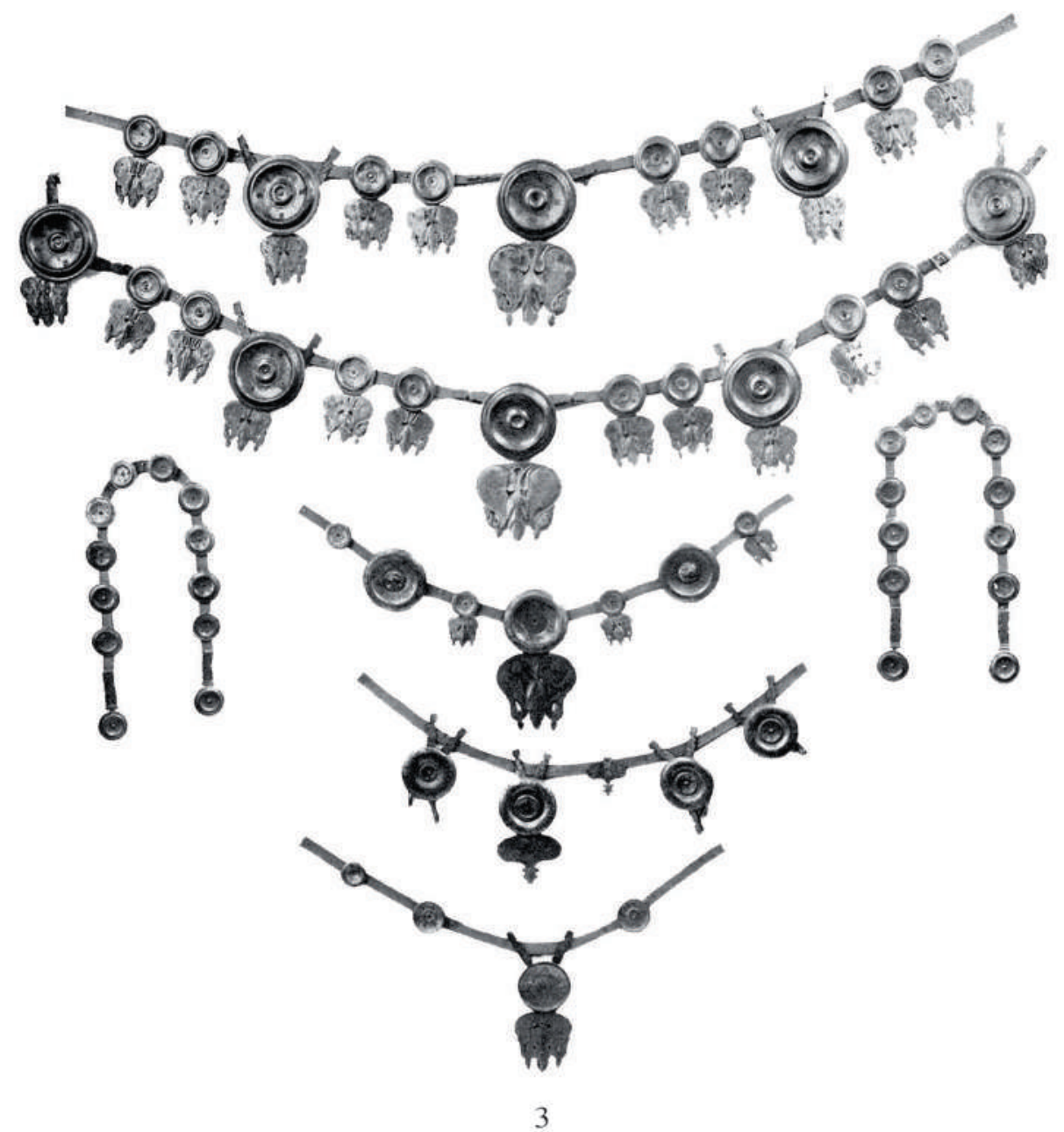

Pl. VI. 1. A very close analogy from Doorwert (after Nicolay 2007, 186, fig. 5.11); 2. Capidava (photo by Al. Rațiu); 3. The entire set discovered at Doorwert (after Nicolay 2007, 186, fig. 5.11). The finds from Capidava resemble in shape and size withe the smaller ones from Doorwert. 


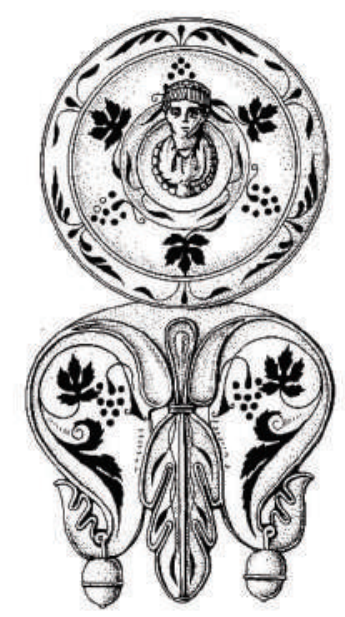

1

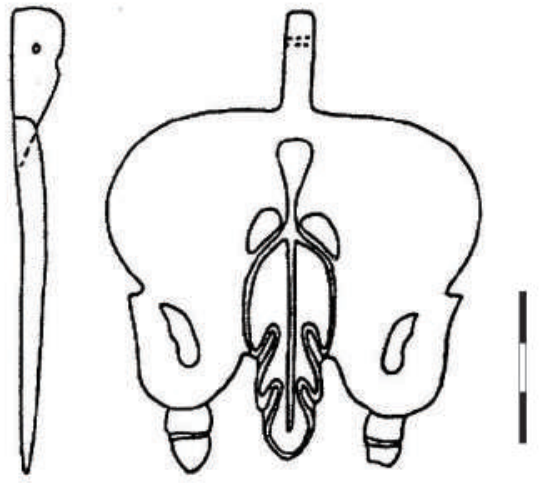

3

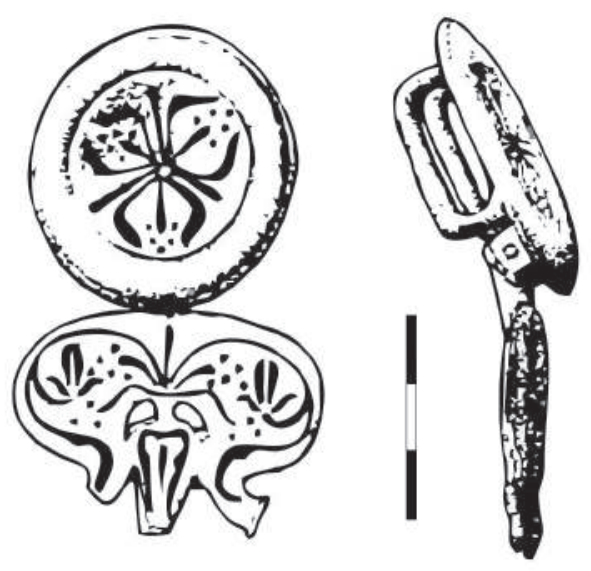

2
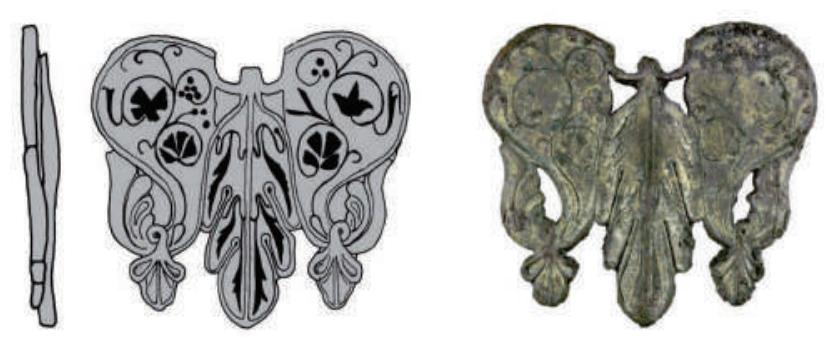

4

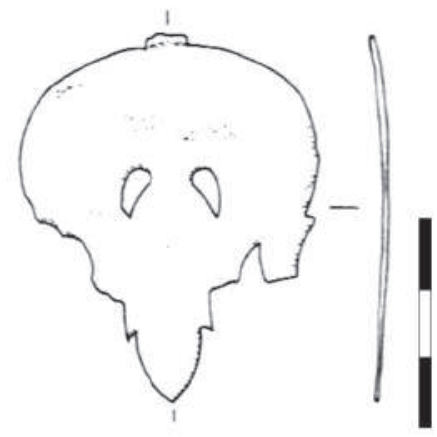

6

Pl. VII. Analogies for the trifid pendants: 1. Xanten (after Nicolay 2007, 144, fig. 4.10; not to scale); 2. Wroxeter (after Bishop and Coulston 2006, 120, fig. 70, no. 8); 3. Prejmer (after Petculescu 1998, 282, Pl. 5/18); 4. Biatorbágy (after Mrav 2010, 154, fig. 3; not to scale); 5. Rottweil (after Dixon and Southern 1992, 69, fig. 38); 6. Dura Europos (after James 2010, 89, fig. 41, no. 190). 


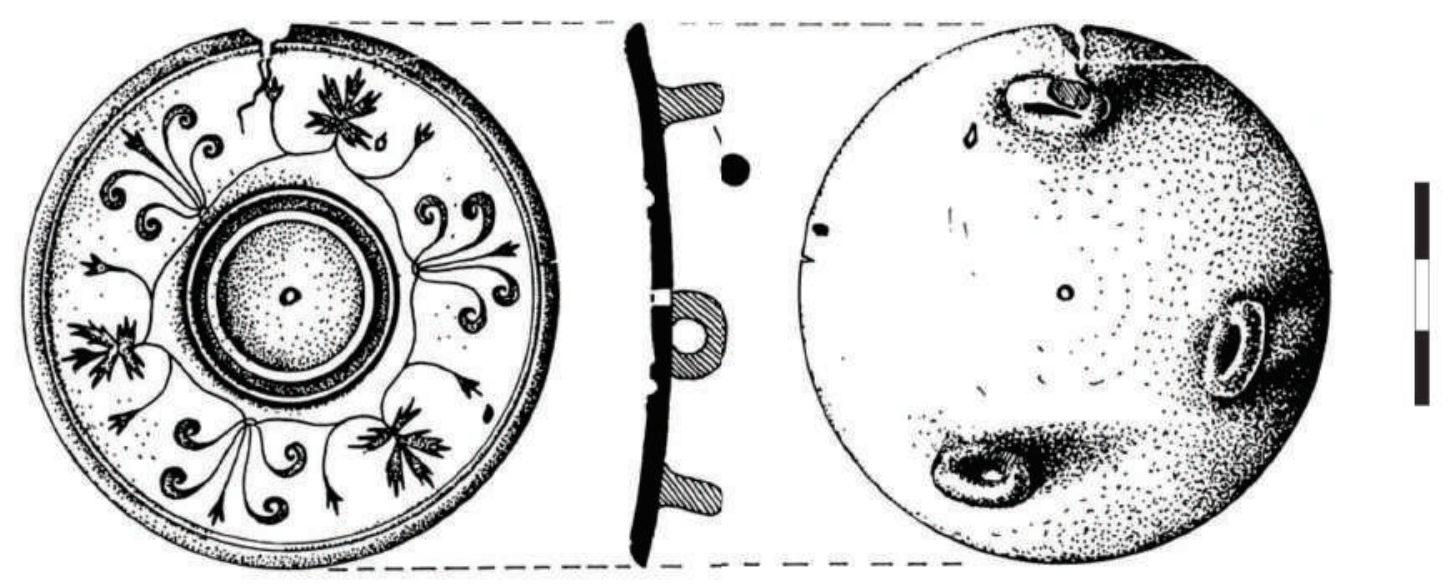

1

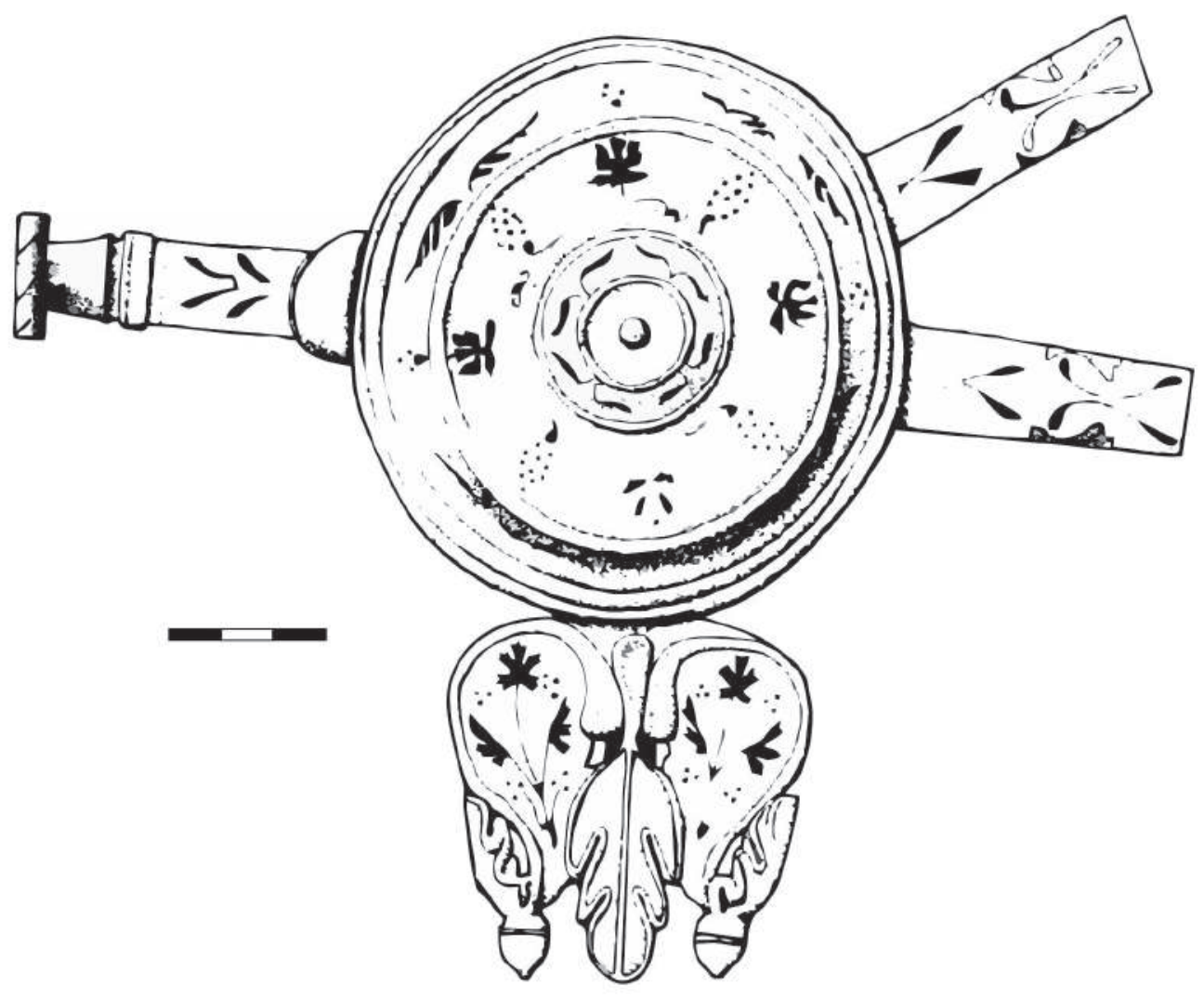

Pl. VIII. 1. Analogies for the trifid pendants: Sarmizegetusa Regia (after Ferencz 2009, 69, fig. 1); 2. Rheingonheim (after Bishop and Coulston 2006, 120, fig. 70, no. 3). 


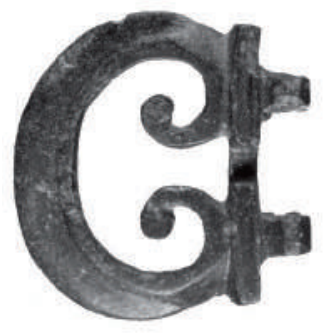

1

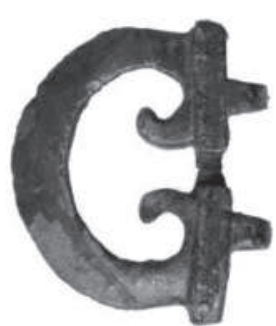

2
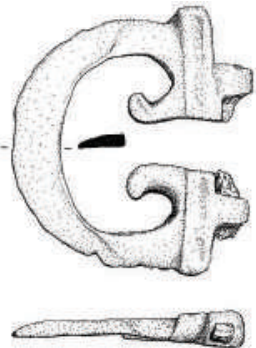

3

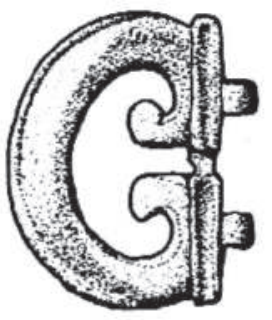

4

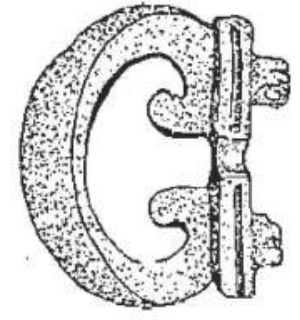

5

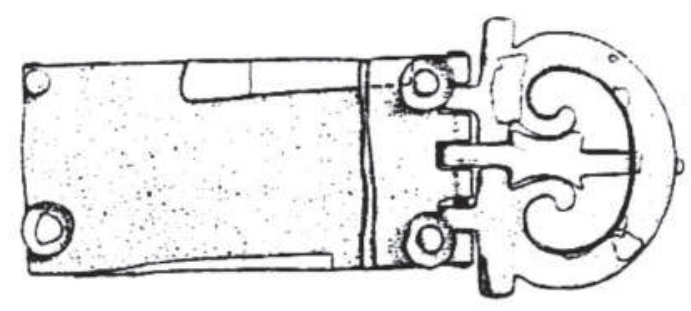

6

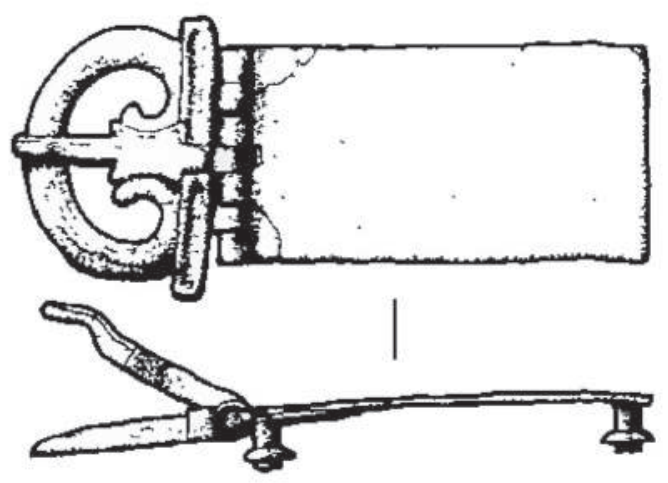

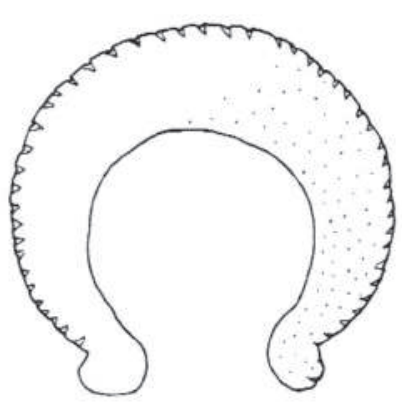

8

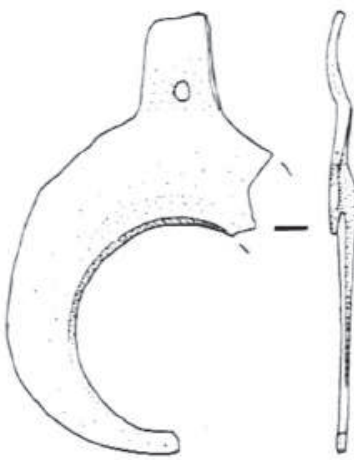

9
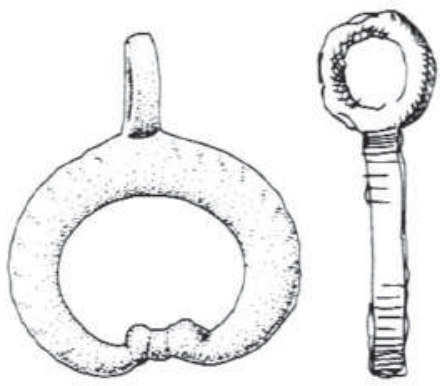

11

Pl. IX. Analogies for the belt buckle and lunula pendant: 1. Wijk bij Duurstede (after Nicolay 2007, 36, fig. 2.11);

2. Gardun/Tilurium (after Radman-Livaja 2010, 76, cat. no. 41); 3. Roecliffe (after Bishop 2005, fig. 27/9);

4. Hod Hill (after Bishop and Coulston 2006, 120, fig. 70, no. 8); 5. Weisbaden (after Oldenstein 1977, taf. 74/971, no. 4, pl. 1/4) ; 6. Velsen (after Bishop and Coulston 2006, 108, fig. 62, no. 19);

7 - 11. Dura Europos (after James 2010, 89, fig. 41, no. 192-198). 


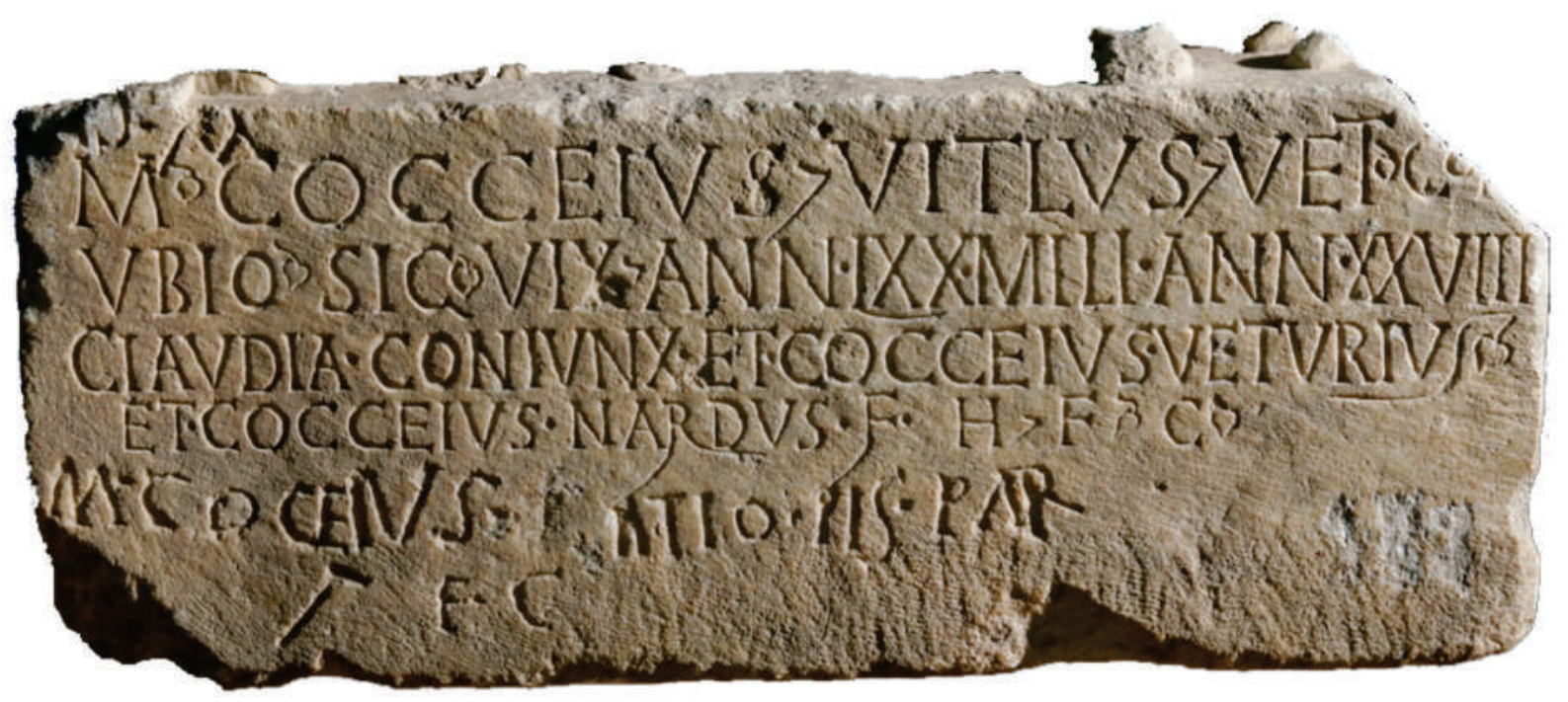

1
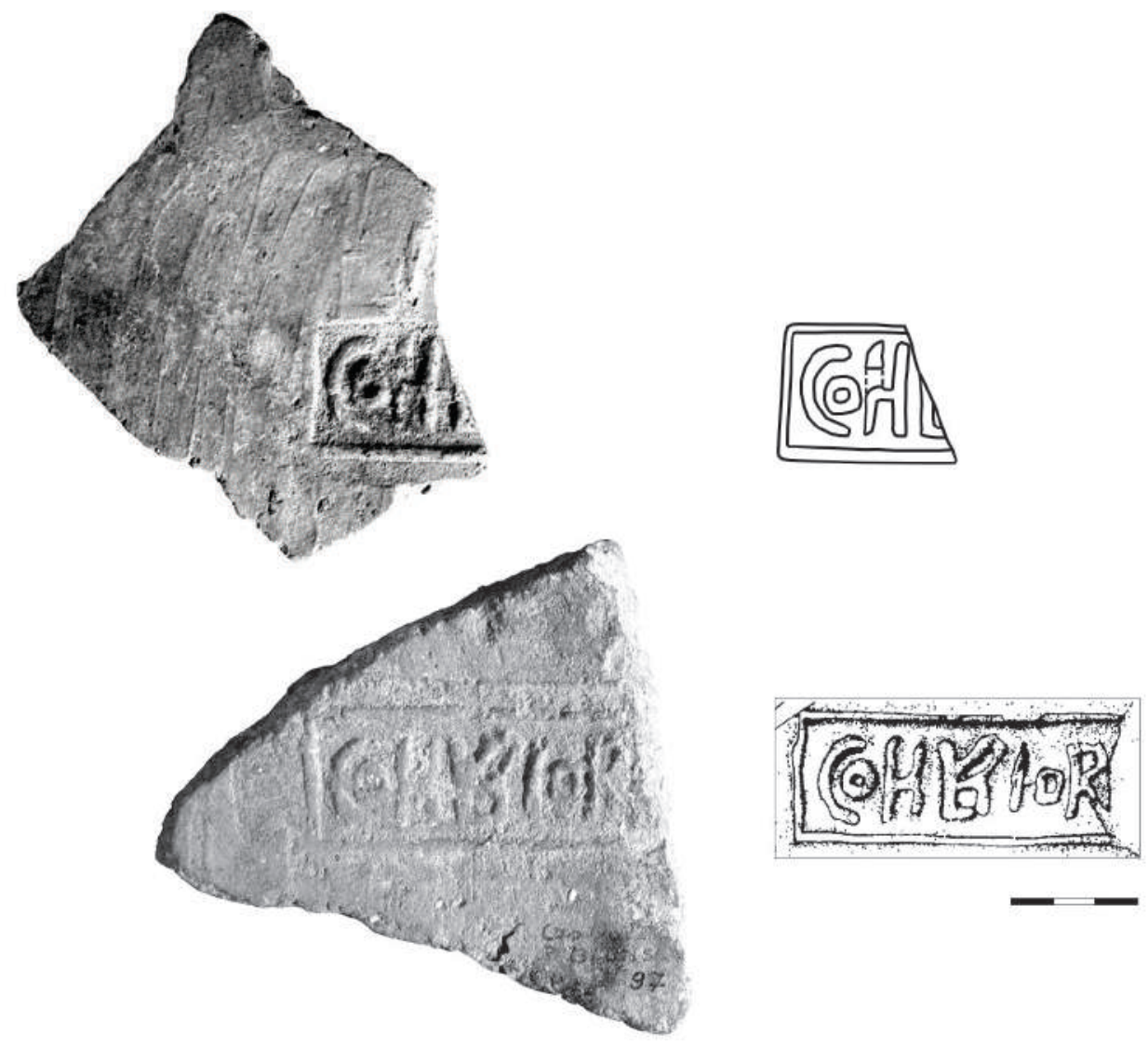

Pl. X. 1. Funerary monument of M. Cocceius Vitlus, veteran of cohors I Ubiorum (C Constanta - Muzeul National de Istorie si Arheologie, Foto: Ortolf Harl 2012, downloaded from http://lupa.at/15214/photos/1);

2. Tile stamp of cohors I Ubiorum (photo I. C. Opriș; drawing Al. Rațiu); 3. Tile stamp of cohors I Ubiorum (photo I. C. Opriş; drawing after Opriş, 1997, 278, fig. 1). 


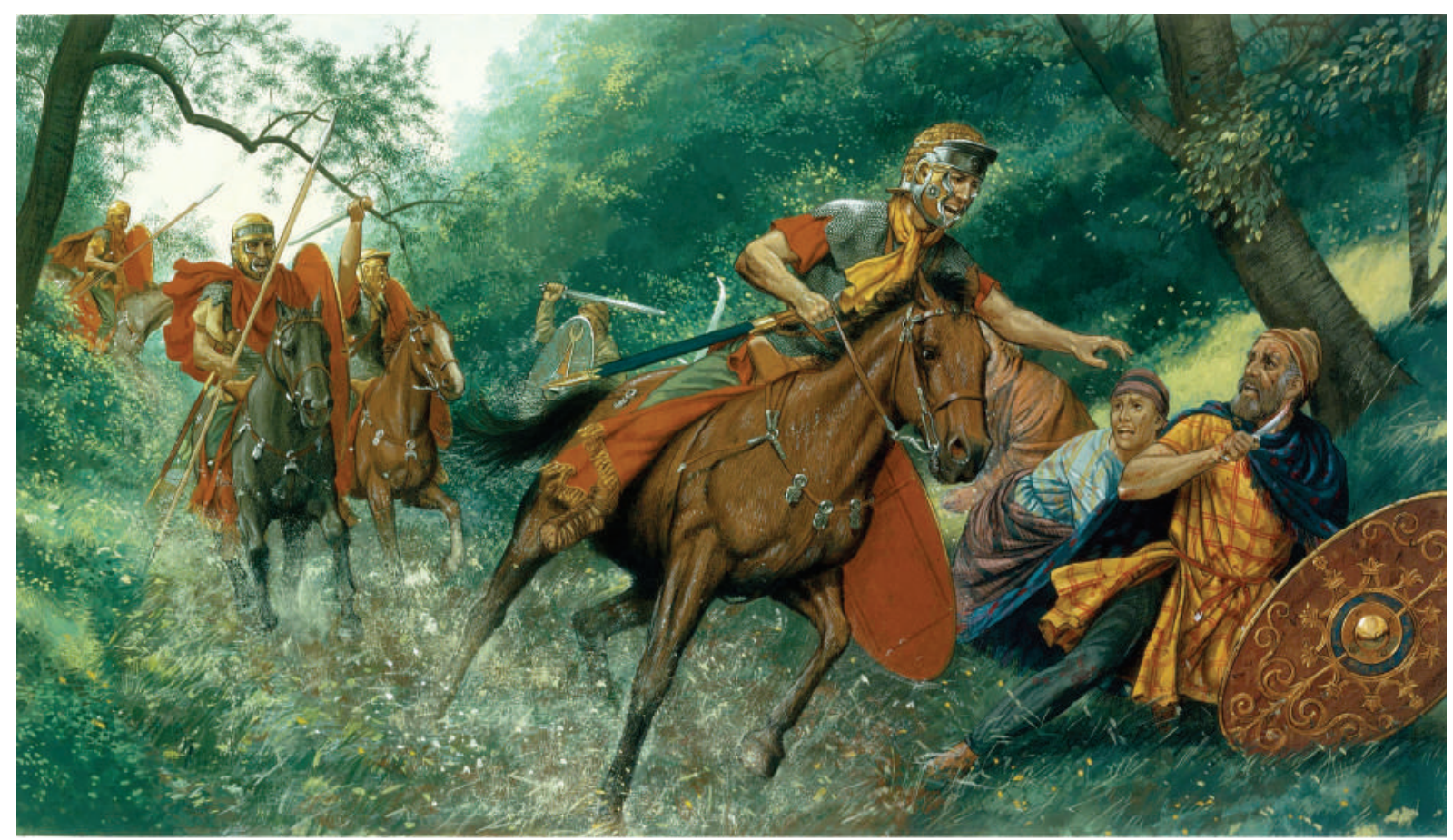

1

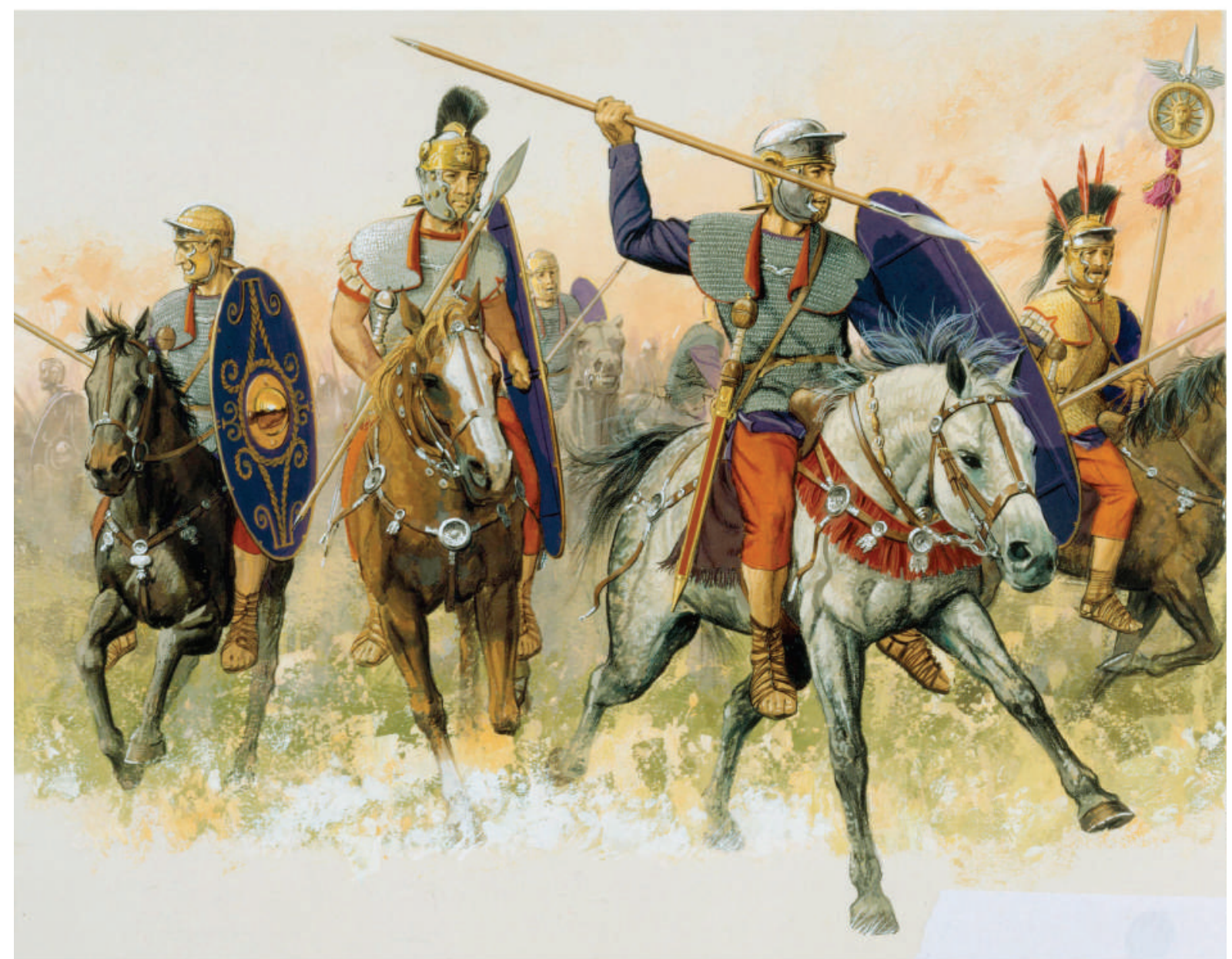

2

Pl. XI. 1 - 2. Graphic reconstructions of various military horse garments of the late $1^{\text {st }}$ - early $2^{\text {nd }} c . A D$.

(C) MNIT, Expo LIMES, drawing by P. Connely). 